\title{
A INFLUÊNCIA DO COMPLIANCE TRIBUTÁRIO E DO PLANEJAMENTO TRIBUTÁRIO NA RECUPERAÇÃO DE CRÉDITOS
}

\section{ARTIGO ORIGINAL}

SILVA, Marcos Oliveira da ${ }^{1}$, ROSA, Dayana Eler², RODRIGUES, Jéssica de Paula ${ }^{3}$

SILVA, Marcos Oliveira da. ROSA, Dayana Eler. RODRIGUES, Jéssica de Paula. A influência do compliance tributário $e$ do planejamento tributário na recuperação de créditos. Revista Científica Multidisciplinar Núcleo do Conhecimento. Ano 06, Ed. 08, Vol. 01, pp. 05-38. Julho de 2021. ISSN: 2448-0959, Link de

acesso:

https://www.nucleodoconhecimento.com.br/contabilidade/recuperacao-de-creditos,

DOI: 10.32749/nucleodoconhecimento.com.br/contabilidade/recuperacao-de-creditos

\section{RESUMO}

Este artigo trata uma das preocupações dos empresários relacionada à alta carga tributária. Visto que, os tributos elevam seus custos e reduzem os seus lucros, abalando diretamente a concorrência no mercado e sua existência, em períodos de instabilidade econômica o processo de recuperação tributária pode ser um aliado para as empresas conseguirem manter as portas abertas. Aqueles tributos pagos indevidos ou a mais, ao serem recuperados, podem representar uma possibilidade de equilíbrio econômico para as empresas enfrentarem momentos difíceis. Desta forma, o presente trabalho tem como questão norteadora: Como as empresas podem ser afetadas na recuperação de crédito através da compliance / planejamento tributário? Visa apresentar a influência do compliance e do planejamento tributário na recuperação tributária. $O$ estudo é desenvolvido a partir de pesquisas bibliográficas de autores e consulta de artigos já publicados. Ademais,

\footnotetext{
${ }^{1}$ Bacharel em Ciências Contábeis (8o período).

${ }^{2}$ Bacharel em Ciências Contábeis (8o período).

${ }^{3}$ Orientadora.
} 
foi aplicado um questionário estruturado para obter dados das experiências de profissionais da área. A análise nos permitiu constatar que o conhecimento sobre a legislação nos possibilita usufruir dos incentivos fiscais e junto a um bom planejamento tributário, podem fazer toda a diferença para o sucesso de uma recuperação tributária.

Palavras-chave: Compliance, Planejamento Tributário, Recuperação de Créditos.

\section{INTRODUÇÃO}

É importante que os profissionais evoluam de acordo com as necessidades do mercado, mantendo assim um bom alinhamento entre seu trabalho e as mudanças nas leis e normas. Atender a legislação é um pré-requisito para a conformidade tributária nas empresas.

Com a atual crise econômica e política, acarreta a queda nas vendas e nos lucros e novamente trouxe à tona o debate sobre quais medidas que se devem adotar para ultrapassar esta turbulência pandêmica com uma saúde financeira adequada. Cabe ao empresário usar toda a sua criatividade e descobrir novas saídas.

Uma boa estratégia, além de se implantar o compliance fiscal e tributário é efetuar a compensação de tributos pagos indevidamente, o que proporciona um rápido retorno de valores ao caixa da empresa melhorando seu fluxo e que somada a outras adequações permitem que a empresa tenha condições de enfrentar momentos tão difíceis. (VIEGAS, 2018).

Dentro deste contexto é de grande importância que se implante um compliance nas áreas tributárias das organizações, minimizando o risco de autuações fiscais e complicações penais, possibilitando um incremento positivo no fluxo de caixa da empresa.

"A carga tributária excessiva e a falta de planejamento estratégico tributário estão entre os fatores que mais contribuem para a elevação do custo das empresas no Brasil", de acordo com o (JORNAL CONTÁBIL, 2020). Entretanto, ao analisarmos 
que o compliance e o planejamento tributário são elementos essenciais no processo administrativo e na recuperação de créditos, onde a inexistência de ambos acarreta inúmeras consequências, dentre elas o enfraquecimento da empresa no mercado.

\begin{abstract}
A legislação tributária do País é uma das mais complexas do mundo, existe uma grande variedade de tributos, obrigações acessórias, leis e normas de cada ente federado regulamentando os tributos e alíquotas de sua competência. E ainda, destaca-se a dificuldade de acesso e comunicação entre os órgãos públicos e as empresas. (CASTRO, 2019).
\end{abstract}

Com essa realidade o compliance e o planejamento tributário em conjunto com uma equipe de profissionais das áreas fiscal, administrativa, contábil e jurídica tributária, podem auxiliar as empresas a melhorar seus processos internos, evitando possíveis retificações de declarações e a manutenção da menor carga tributária possível, cumprindo as normas impostas pelo Fisco e atentos às mudanças frequentes da legislação fiscal. Esse é o resultado esperado da eficácia do trabalho em conjunto do compliance, planejamento tributário e de uma equipe capacitada que através das normas, identifica meios legais de cumprir as obrigações principais, acessórias, além das possibilidades de redução tributária através de créditos e compensações.

Dado este contexto a pesquisa será desenvolvida sobre a temática a eficiência do compliance e do planejamento tributário na recuperação de créditos e no processo de delimitação do tema, optou-se pelo seguinte problema: Como as empresas podem ser afetadas na recuperação de crédito através da compliance / planejamento tributário?

Souza e Pavão (2012), enfatizam a importância de um bom planejamento tributário e econômico dentro do resultado da empresa, visto que muitas pesquisas relataram que quase $40 \%$ dos rendimentos gerados em uma organização se destinam ao pagamento de tributos. Muitos deles às vezes indevidos, pagos a maior elevando seus custos e prejudicando os seus fluxos de caixa.

Assegurada por lei, as empresas podem reaver tributos através da recuperação de créditos, que nada mais é que o valor do tributo devido pelo sujeito passivo de uma 
obrigação tributária ao sujeito ativo, trazendo benefícios para as empresas reforçando seus caixas em momentos de crise econômica. O objetivo geral desta pesquisa será identificar como o compliance / planejamento tributário afeta as empresas na recuperação de créditos, para atingir o objetivo proposto, faz-se necessário os seguintes objetivos específicos.

- Conceituar compliance / planejamento tributário e suas vantagens e desvantagens;

- Explanar sobre a história da tributação no Brasil;

- Mensurar o que é e como é feita a recuperação de crédito;

- Aplicação de um questionário estruturado junto a algumas empresas quanto à utilização do compliance / planejamento tributário na recuperação tributária, nos municípios da Grande Vitória;

- Analisar e demonstrar as informações coletadas da pesquisa.

Com a análise da visão fiscal será possível identificar o nível de conhecimento dos gestores sobre a tributação das operações da empresa e onde a falta de um compliance / planejamento tributário dificulta e leva as empresas deixarem de se beneficiar dessa possível recuperação de créditos tributários que foram recolhidos indevidamente.

\section{TRIBUTAÇÃO NO BRASIL}

Conforme o IBPT Educação (2018), a tributação no Brasil foi criada nos primeiros anos de colonização aparentemente igual ao modelo egípcio. Isso porque os exploradores que se interessassem pelo Pau-Brasil (espécie de árvore nativa) tinham que pagar a quinta parte do material explorado à coroa portuguesa. Esse sistema servia também para outras riquezas do país que eram extraídas.

Com a separação do Brasil em capitanias hereditárias governadas por donatários, esse sistema evoluiu mesmo ainda não existindo uma moeda, consistindo no 
monopólio monárquico sobre as riquezas do Brasil. Ele tinha a própria matéria como forma de pagamento.

Após o sistema de capitanias ter falhado no país, em 1549 foi instalado o Governo Geral, para tentar instaurar a ordem na colônia, centralizando a administração e a cobrança de tributos.

Após a instalação da família real em 1808, o país passou a usar moedas de ouro, prata e cobre. Surgindo a necessidade da criação de um novo tributo para custear a mudança da coroa para o Brasil, com a centralização no Brasil, as relações de comércio internacional aumentaram, originando a tributação sobre importação dos produtos.

A partir deste período, houve inúmeras alterações em nosso sistema tributário brasileiro, que foi se tornando cada vez mais complexo na medida em que a economia se fortalecia. $O$ interessante é que, como esse modelo extremamente primitivo ainda gera reflexos no atual sistema tributário brasileiro.

Segundo Lima e Rezende (2017), a tributação no Brasil atingiu quase $40 \%$ do Produto Interno Bruto (PIB) sendo uma das maiores cargas tributárias a nível mundial. Por isso, o custo dos produtos e serviços produzidos no país tendem a ser altos. Atualmente, no Brasil, os governos têm adotado medidas que aumentaram a carga tributária. Convertidas em receitas, a fim de gerar recursos para a realização dos objetivos públicos.

Em função do aumento da carga tributária e suas consequências nas empresas e na sociedade, frequentemente surgem discussões e debates no Brasil sobre a reforma do sistema tributário. Outro fator preocupante é a evasão tributária, pois estudos vêm sendo desenvolvidos a fim de identificar motivos que levam o contribuinte a sonegar impostos. 
Pensando em arrecadar cada vez mais, devido ao aumento das despesas, do aumento de investimentos públicos, além de elevar a carga tributária, o governo vem realizando cruzamentos de dados através de meios eletrônicos, dificultando a sonegação e reduzindo a inadimplência. Por isso, mesmo apurando de forma lícita os tributos, as organizações devem ter uma gestão transparente, para manter a sua competitividade no mercado.

Com a abertura comercial internacional que surgiu na década de 90 , o Brasil se viu obrigado a se adequar as regras mundiais para maior segurança das instituições financeiras, pois quem aderisse à política de mercado ligada ao compliance tinha uma aceitação maior no mercado internacional.

O termo compliance encontra-se em destaque, pois com a Operação Lava-Jato, maior investigação de combate à corrupção e lavagem de dinheiro da história do Brasil, estima-se que o volume de recursos desviados dos cofres públicos esteja na casa de bilhões de reais, tendo apresentado resultados eficientes, recuperando valores recordes para os cofres públicos, ficou claro que muitas empresas não estavam cumprindo com seu dever de compliance e muitas nem sabiam que existia, com o advento da Lei 12.846/13 (Lei Anticorrupção) estas empresas se viram obrigadas a aderir à ideia, causando assim um impacto em seu planejamento tributário.

\section{PLANEJAMENTO TRIBUTÁRIO}

O planejamento tributário ou elisão fiscal trata-se de um processo de organização das atividades operacionais e financeiras da empresa, que utilizado como uma ferramenta de gestão pode encontrar meios e métodos para uma futura redução de valores pagos em tributos pela empresa em suas operações e produtos.

O planejamento tributário é considerado uma ferramenta imprescindível para as empresas não pagarem impostos abusivos, mas sim o mínimo exigido em lei. Pode ser definido com o conjunto de medidas tomadas com o intuito de reduzir o pagamento de tributos, de forma legal e levando em consideração 
as possíveis mudanças de forma rápida e eficaz caso o fisco altere as regras fiscais. (OLIVEIRA, 2013).

De acordo com Santos e Brito (2016, p. 4) o planejamento tributário "infere um estudo das obrigações tributárias devidas pela empresa, que busca dentro da legislação obter uma economia dos tributos e redução da carga tributária".

Mas para podermos entender melhor o real significado do termo planejamento tributário, precisamos saber alguns pontos relevantes sobre sua real necessidade de existência dentro da empresa, tais como: Métodos de planejamento, regime tributário.

\subsection{PLANEJAMENTO TRIBUTÁRIO}

Define Souza e Pavão (2012, p. 2) planejamento tributário como "um conjunto de sistemas legais que visam diminuir o pagamento dos tributos, e o contribuinte que pretende diminuir estes encargos, poderá fazê-lo legal ou ilegalmente". Fazer este estudo pode trazer para a organização grandes benefícios possibilitando a ela o alcance de melhores resultados financeiros.

Segundo Feitosa (2020), destaca-se três métodos de planejamento tributário: Operacional, Estratégico e Tático. Onde é necessário conhecer todos os setores da empresa, definindo objetivos e formas para atingir as metas traçadas, para facilitar e saber a hora de adotá-los como estratégia e ter eficiência na execução.

Planejamento operacional age de acordo com a legislação em vigor, buscando cumprir as obrigações e deveres em um determinado tempo, tem o intuito de alcançar o objetivo projetado, com novas atividades e os responsáveis pela sua realização. O planejamento estratégico é realizado em longo prazo, geralmente é elaborado para o período de 5 a 10 anos sendo sempre atualizado anualmente. E o planejamento tático é focado no médio prazo, entre 1 a 3 anos, voltado para setores específicos da empresa, tem maior detalhamento de informações que o estratégico. 


\section{COMPLIANCE}

A origem do termo compliance vem do verbo inglês "ToComply", significando cumprir uma norma, agir obedecendo e estabelecendo regra.

Conforme documento elaborado pelas associações de bancos ABBI (Associação Brasileira de Bancos Internacionais) e FEBRABAN (Federação Brasileira de Bancos), o compliance é o dever de cumprir, estar em conformidade e fazer cumprir os regulamentos internos e externos impostos às atividades da organização. E também está relacionado ao investimento em pessoas, processos e conscientização. Portanto, é preciso que as pessoas estejam conscientes sobre a importância de ser e estar em compliance. Está "em compliance é estar em conformidade com leis e regulamentos internos e externos. (FEBRABAN, 2003).

Segundo Giovanini (2014, p. 20), a ideia do compliance excede o simples atendimento à legislação, sendo elemento importante para o ambiente empresarial em que também existam preceitos morais de honestidade e transparência, não somente na administração dos negócios, mas em todas as condutas de um ambiente corporativo.

Já no compliance tributário que nada mais é do que uma revisão ou checagem que as empresas fazem para combater eventuais divergências fiscais, sempre fundamentada em toda legislação em vigor garantindo assim uma boa gestão, evitando de forma eficaz e lícita possíveis penalidades fiscais que possam vir a ocorrer, que poderão afetar o patrimônio das empresas e em alguns casos o patrimônio dos sócios.

\subsection{COMPLIANCE X PLANEJAMENTO TRIBUTÁRIO}

No Brasil teve início em 2014, com a criação da lei anticorrupção № 12.846 de 1ำ de agosto de 2013, que incentiva as empresas a tomar medidas de organização fiscal, muitas empresas não possuem uma estrutura e não conseguem estruturar seus setores fiscais sem a ajuda do compliance / planejamento tributário, que tem como o 
objetivo a avaliação e organização dos processos fiscais das empresas. Para isso a existência de um planejamento tributário consolidado se faz necessário.

O planejamento tributário pode ser entendido como o planejamento empresarial que tem como objeto a análise dos tributos e seus reflexos na organização e objetivo de economia de impostos, adotando procedimentos estritamente dentro da legalidade. É uma forma prévia de analisar os fatos administrativos e fiscais, buscando a forma menos onerosa para a concretização dos negócios empresariais. (SIQUEIRA, 2011).

Compliance e planejamento tributário são institutos distintos, cada qual com suas especificidades, mas que se completam. A união desses dois elementos essenciais nas atividades da empresa desencadeia uma série de acontecimentos que favorecem o crescimento da organização, por exemplo, a redução de custos, menor incidência de multas, a melhora da sua imagem no mercado em contrapartida, a ausência deles põe a empresa em "risco de compliance", podendo afetar as finanças da empresa exemplificada aqui por uma possível recuperação de créditos tributários.

A expressão "risco de compliance" é definida como risco legal, de sanções regulatórias, de perda financeira ou perda de reputação, que uma organização pode sofrer como resultado de falhas no cumprimento de leis, regulamentações, códigos de conduta e das boas práticas. (COIMBRA; MANZI, 2010, p. 42).

O compliance aplicado ao planejamento tributário realizado nas empresas trará a elas maior transparência, alta produtividade, redução de pagamentos de tributos, vantagens competitivas e visibilidade externa favorável. Desta forma, é possível compreender que o compliance está intrinsecamente ligado a um planejamento tributário efetivo.

\subsection{RECUPERAÇÃO DE CRÉDITO}

A recuperação de crédito tributário é uma atividade que envolve o levantamento e o resgate dos créditos que foram acumulados no decorrer dos anos, sendo um direito assegurado por lei, podendo receber de volta valores de tributos pagos indevidamente, ou seja, é preciso ter um planejamento tributário minucioso. 
Crédito é toda prestação efetivada através de uma operação monetária mediante uma contraprestação correspondente futura, o que torna fundamental que o credor confie na solvência do devedor, já que este saldará o débito somente em momento posterior. (RIZZARDO, 2003, p. 16).

Com as dificuldades financeiras que muitas empresas vêm vivenciando nos últimos tempos, inclusive pela falta de conhecimento relacionada aos impostos devidos, o fisco tem recebido milhões de reais em tributos que nunca deveriam ter saído do caixa das empresas. A contagem do prazo tem início a partir da data em que o crédito tributário foi constituído, ou seja, terá o prazo de até 05 (cinco) anos para fazer o requerimento da devolução do valor do tributo que foi pago indevido ou a maior. Com esse prazo expirado a empresa não terá mais direito à restituição ou a compensação, em função da prescrição (perda do direito).

\subsubsection{RECUPERAÇÃO DE CRÉDITO TRIBUTÁRIO}

Antes de formalizar uma solicitação de recuperação de crédito tributário, é preciso fazer uma abrangente revisão tributária, cruzando os diferentes dados com a jurisprudência, para então a empresa apresentar o pedido eletrônico de restituição, ressarcimento ou reembolso e a declaração de compensação (PER/DCOMP), podendo ser feitas através de dois métodos.

\subsubsection{ADMINISTRATIVO}

Segundo Dome (2019), a recuperação tributária é uma ferramenta que garante ao contribuinte o recebimento dos tributos que são devidos indevidamente ao governo. O que muitos desconhecem é que este processo também pode ser feito pelo próprio contribuinte de maneira administrativa, ou seja, com menor burocracia e sem a necessidade de abrir um processo jurídico, garantindo o seu direito de beneficiamento ao uso dos créditos, ou ainda, o questionamento sobre a cobrança indevida de seus débitos.

A recuperação de crédito tributário via administrativa é feita através da formulação do documento PERDCOMP - Pedido eletrônico de ressarcimento 
e declaração de compensação. Por meio dele deve se apurar o crédito que a empresa tem direito a reaver e o mesmo poderá ser compensado com outros tributos administrados pela Receita Federal. (SANTOS, 2020).

O autor Santos (2020) ainda descreve que a restituição administrativa se refere a erros no recolhimento de tributos, isso pode ocorrer quando se preenche as informações de apuração ou o código da receita de forma errada, guias erradas e até mesmo tributo pago duplicadamente.

\section{JUDICIAL}

É o procedimento na qual o poder judiciário é acionado pelo credor com o intuito de coagir judicialmente por meio de instrumentos próprios, o pagamento pelo devedor de um crédito devido.

Todo tributo pago de forma indevida pode ser questionado judicialmente. Basta apenas a análise, o recolhimento de toda informação encontrada e entrar com ação judicial onde o pedido será analisado pelo juiz. Existem dois casos de créditos tributários que podem somente ser recuperados judicialmente.

Créditos cuja restituição na via administrativa foi negada, onde havendo o indeferimento do pedido administrativo de restituição o cliente tem o prazo de 2 anos para tentar buscar a anulação da decisão e fazer uma nova solicitação da devolução. $E$ os créditos que envolvem discussão de legitimidade do tributo cobrado onde existe 0 enquadramento das chamadas teses tributárias, que são fundamentadas na análise da constitucionalidade e da legalidade de diversos aspectos dos tributos.

Depois de concluída a análise tributária e o valor que deve ser recuperado encontrado, o mesmo pode ser solicitado pelo cliente de duas formas: Restituição O contribuinte solicita que o valor recuperado retorne à empresa de maneira pecuniária. Sendo depositado pelo órgão devedor em uma conta jurídica, assim como foi feito o pagamento pela empresa. E compensação - quando o contribuinte 
solicita a compensação dos seus créditos tributários em outro tributo. Ou seja, o valor recuperado é abatido de pagamentos de tributos futuros da mesma esfera de governo.

\section{METODOLOGIA}

A pesquisa utilizou-se de um questionário objetivo como ferramenta de coleta, tratamento e análise de dados qualitativo e descritivo. Tem caráter exploratório, no sentido de obter maiores informações sobre o assunto em questão, com finalidade de formular problemas e abrir espaço para discussões posteriores.

De acordo com Gil (2010), "Esse tipo de levantamento classifica-se como uma survey, isto é, um tipo de levantamento no qual "as pesquisas se caracterizam pela interrogação direta das pessoas cujo comportamento se deseja conhecer".

A importância de uma pesquisa qualitativa é coletar informações não numéricas para explorar características individuais ou de grupo, que produz achados não acessíveis por procedimentos estatísticos ou outro meio quantitativo.

O presente estudo utilizou a metodologia científica de pesquisa, fazendo parte do trabalho o referencial teórico, bem como a pesquisa feita através de um questionário aplicado online junto às empresas.

Este trabalho contempla uma análise qualitativa, em relação à percepção das empresas quando se aderem e colocam em prática o planejamento tributário para que futuramente não terem que recorrer a recuperação de crédito.

\section{AMOSTRA E COLETA DE DADOS}

A pesquisa foi realizada no mês de novembro de 2020 e a amostra para este estudo foi retirada de 10 empresas operantes na Grande Vitória, sendo consideradas 10 empresas respostas válidas, ou seja, 100\% de êxito nas respostas obtidas. 
Para melhor compreensão do tema abordado foram colhidas informações junto aos administradores, analistas, CEO, contadores, gerentes de contabilidade e sócios das empresas participantes, após aplicação do questionário, as informações foram analisadas por meio de gráficos para melhor observação dos resultados obtidos e em seguida interpretados com base nas respostas.

\section{APRESENTAÇÃO E ANÁLISE DOS RESULTADOS}

\subsection{PERFIL DA AMOSTRA}

O ponto de partida foi entender o perfil dos respondentes, bem como sua atuação no âmbito empresarial. No primeiro gráfico, nota-se que quase a metade dos respondentes (40\%) são contadores na empresa em que atuam. Seguidos de sócios (20\%), administradores (10\%), analistas (10\%), CEO (10\%) e gerente de contabilidade (10\%).

Gráfico 1 - Cargo

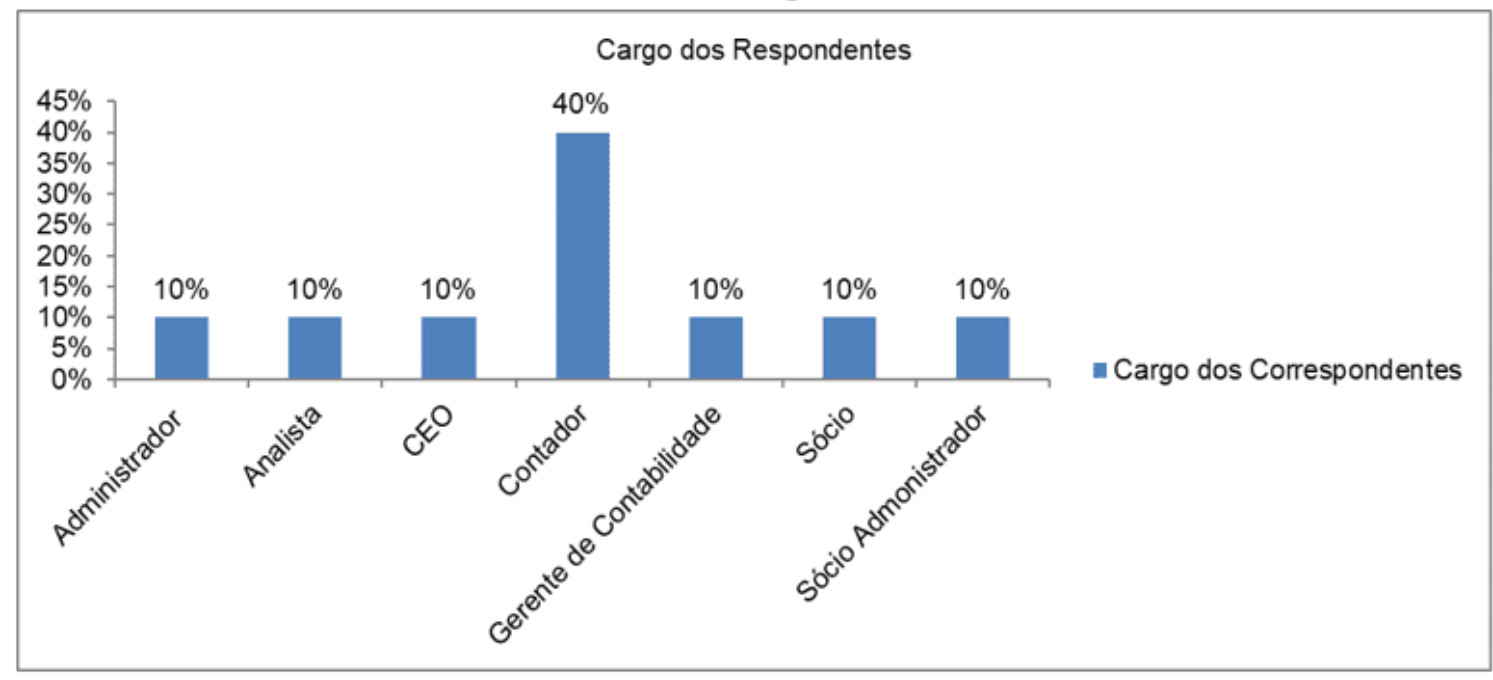

Fonte: Dados da pesquisa 2020.

O gráfico a seguir mostra que o campo de pesquisa foi aberto a região da grande Vitória, sendo Vitória (50\%), Serra (40\%) e Vila Velha (10\%), quando questionados 
sobre tempo de existência da empresa, todos os respondentes responderam que já existem no mercado há mais de 05 anos.

Gráfico 2 - Localidade

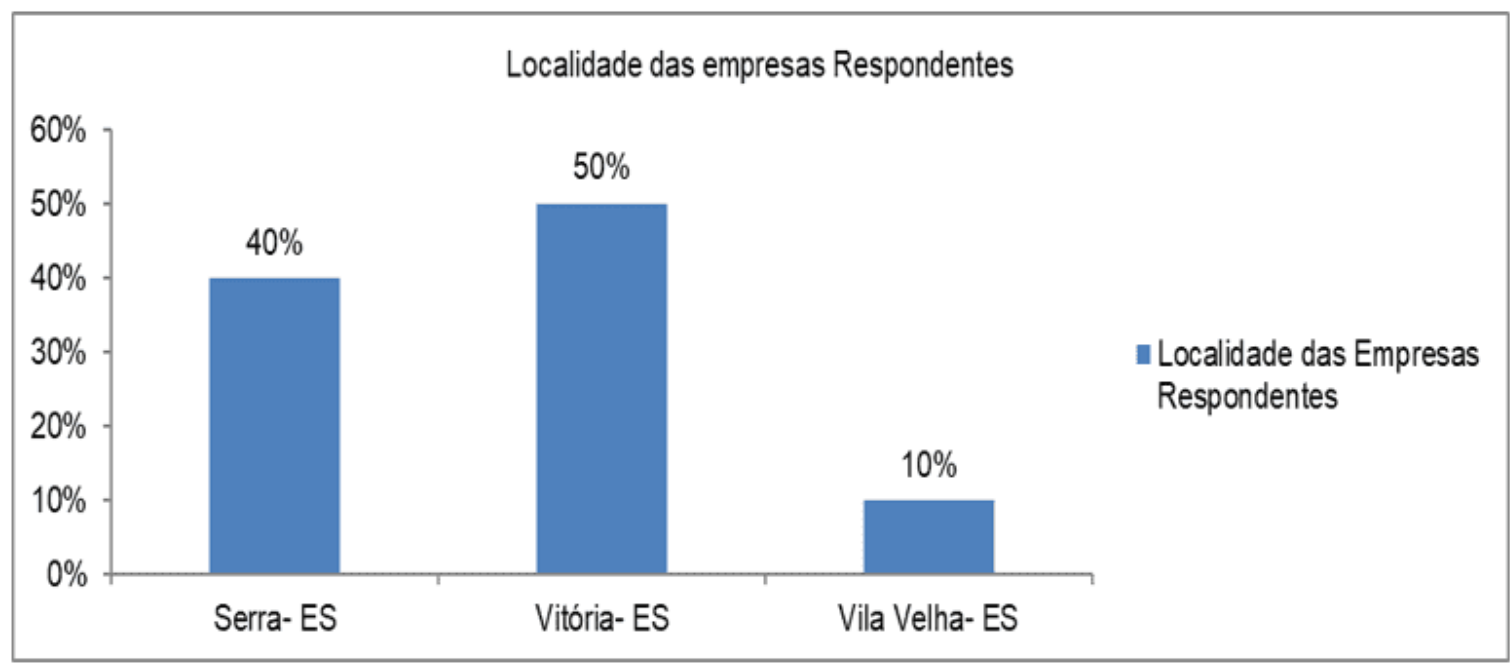

Fonte: Dados da pesquisa 2020.

Nos gráficos a frente denominados 3 e 4, constata-se a tipologia empresarial bem diversificada, sendo sociedade empresarial Limitada LTDA (30\%), empresa de pequeno porte $(30 \%)$, empresa de responsabilidade limitada EIRELI $(20 \%)$ e sociedade anônima S/A (20\%). Onde se verificou também, a distribuição por segmento de atuação das empresas. Atestando que, (80\%) da amostra atua no setor de prestação de serviços e (20\%) comércio. A pesquisa não alcançou as empresas de indústria. 
Gráfico 3 - Tipo

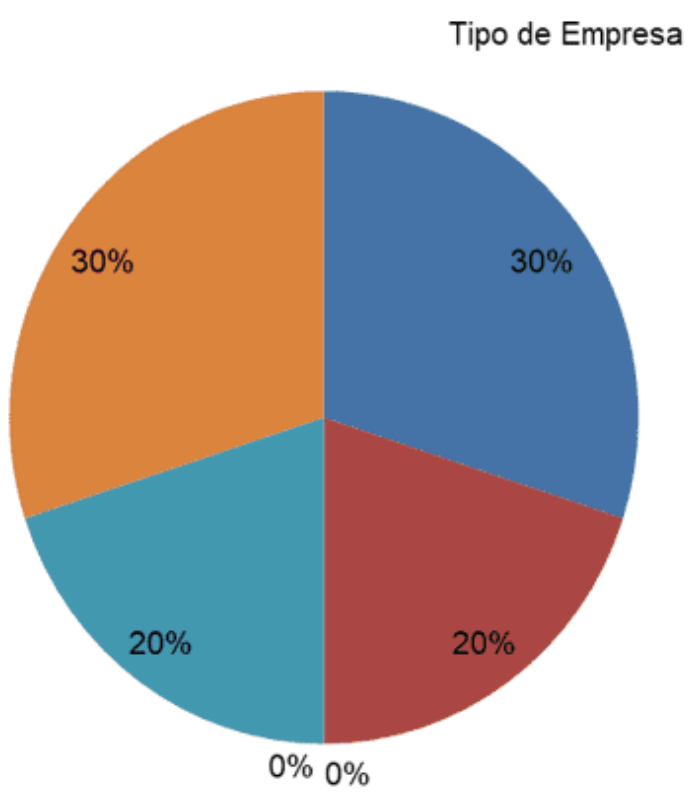

- Sociedade Empresária Limitada (Ltda)

-Empresa Individual de Responsabilidade Limitada (Eireli) (MEI)

" Sociedade Simples (SS)

n Sociedade Anônima (SA)

Empresas de pequeno porte (EPP)

Fonte: Dados da pesquisa 2020.

Gráfico 4 - Segmento

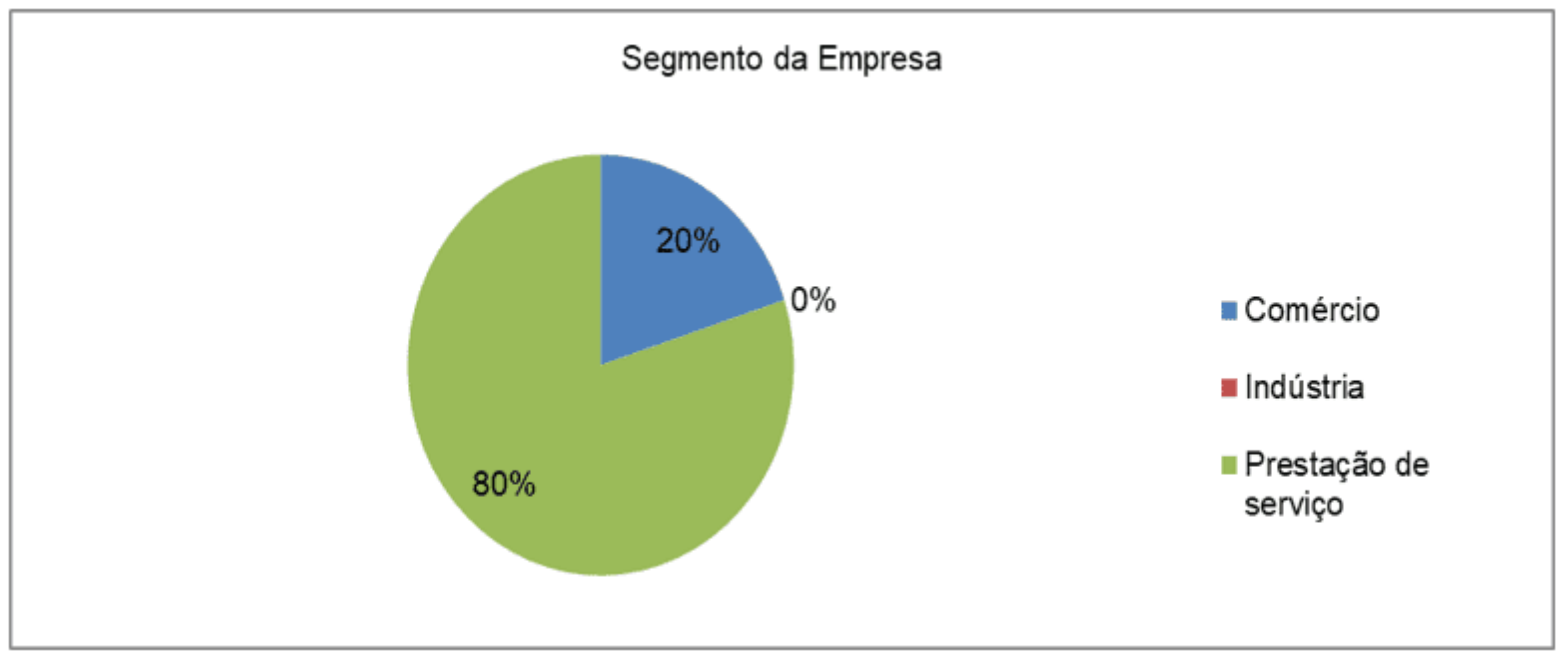

Fonte: Dados da pesquisa 2020.

RC: 93101

Disponível em:

https://www.nucleodoconhecimento.com.br/contabilidade/recuperacao-de-creditos 


\subsection{ANÁLISE DOS DADOS}

As empresas de todos os portes, sofrem com a complexa carga tributária do Brasil. Para amenizar a situação ter um planejamento tributário e a aplicação de algumas práticas se faz necessário, o gráfico 6 apresenta as respostas obtidas.

Gráfico 5 - Práticas de planejamento tributário

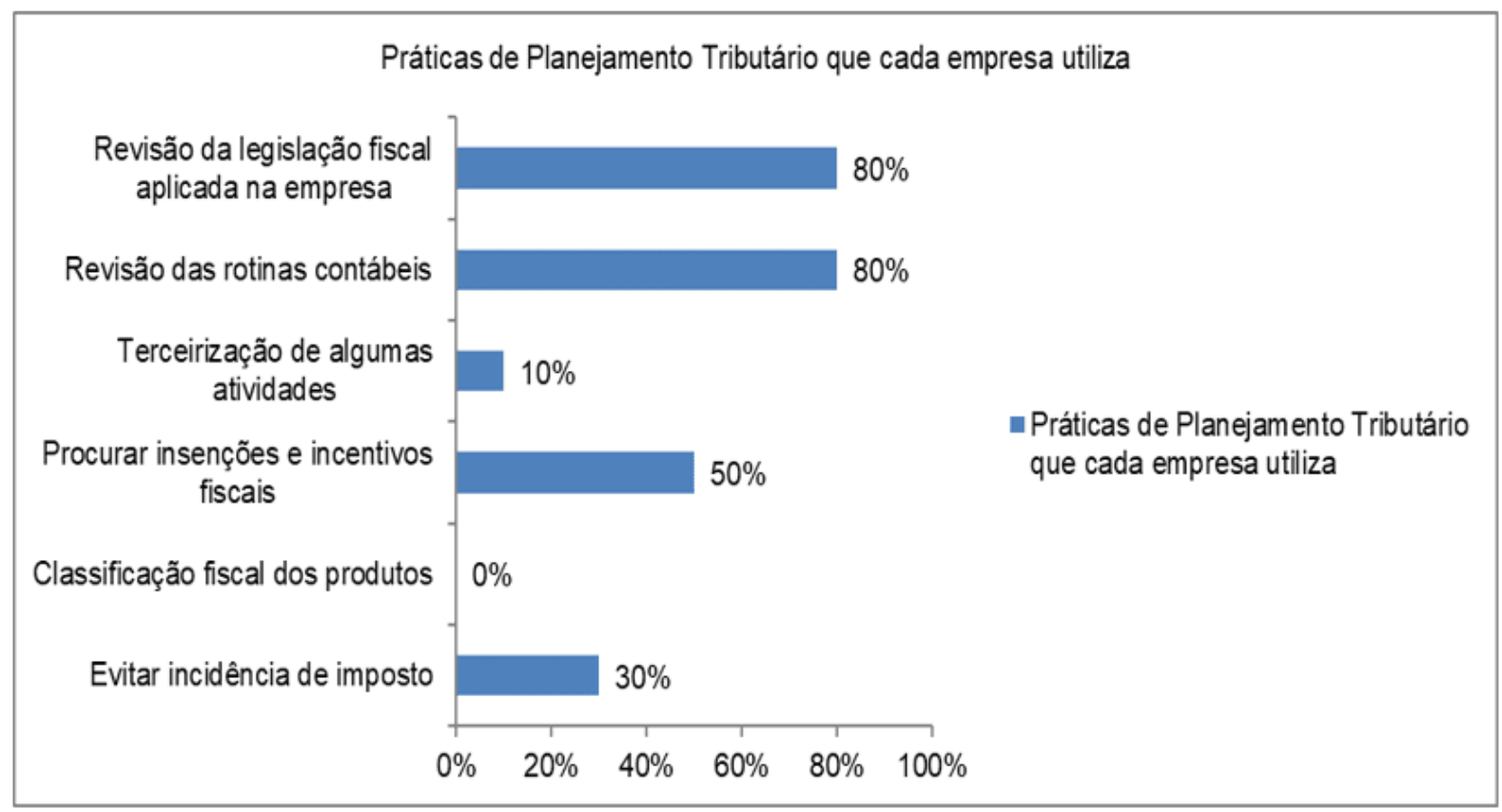

Fonte: Dados da pesquisa 2020.

Quanto à utilização das práticas de compliance tributário pelas empresas os respondentes revelaram que, quando a organização está em compliance significa que ela está em conformidade atendendo as exigências do fisco vigentes na legislação brasileira. Porém, algumas práticas como nos mostra o gráfico abaixo, devem sem implementadas, melhorada e continuada, diminuindo riscos, multas, aumento de custos etc. 
Gráfico 6 - Práticas de compliance tributário

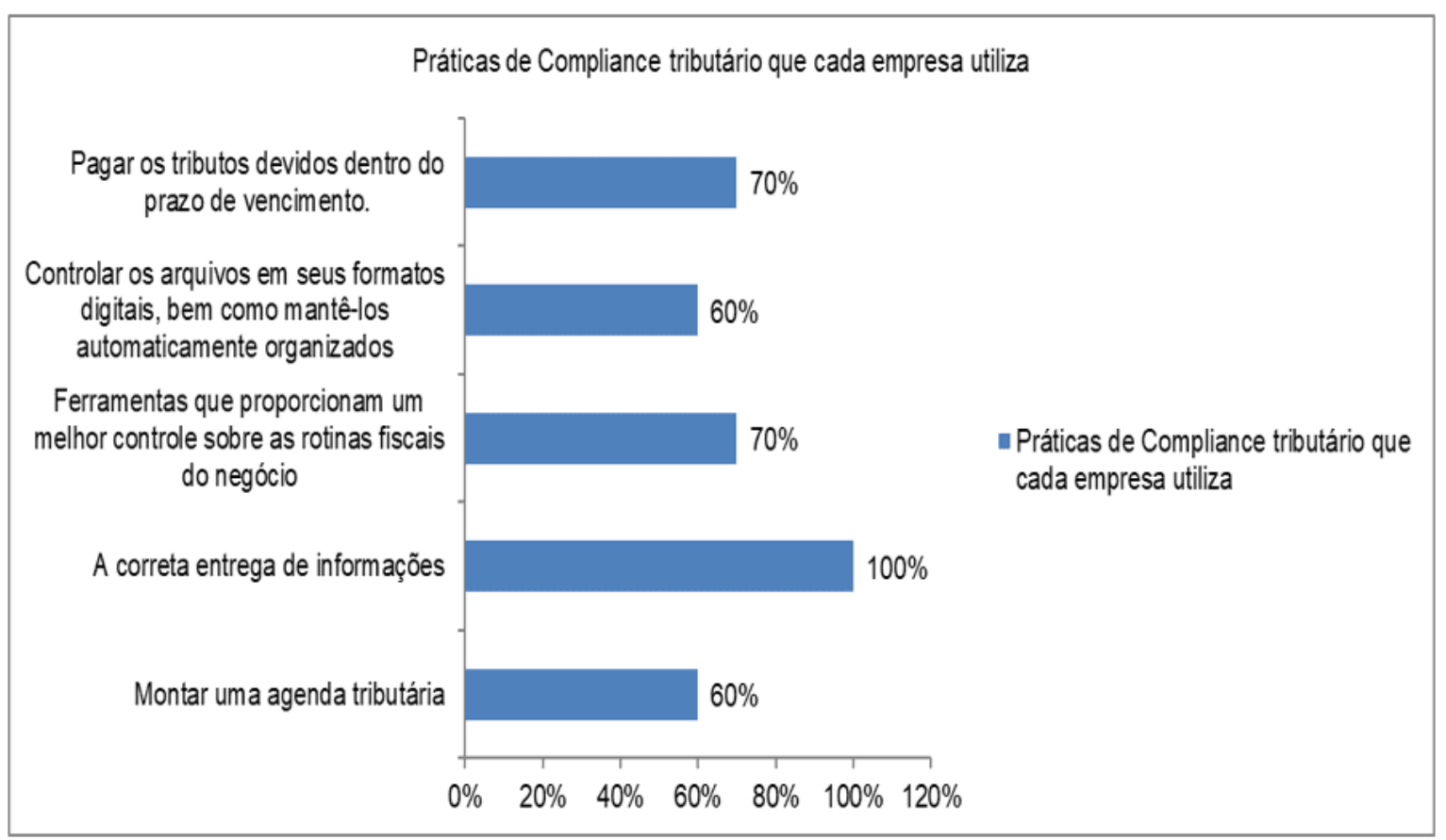

Fonte: Dados da pesquisa 2020.

Quanto ao tipo de planejamento tributário mais utilizado nas empresas selecionadas, os respondentes preferiram operacional e estratégico, que são utilizados por $70 \%$ destes. Já tático e corretivo são utilizados por apenas $20 \%$ e 30\% dos respondentes, respectivamente, o que pode estar relacionado com o cumprimento das metas estabelecidas. 
Gráfico 7 - Planejamento tributário mais utilizado nas empresas

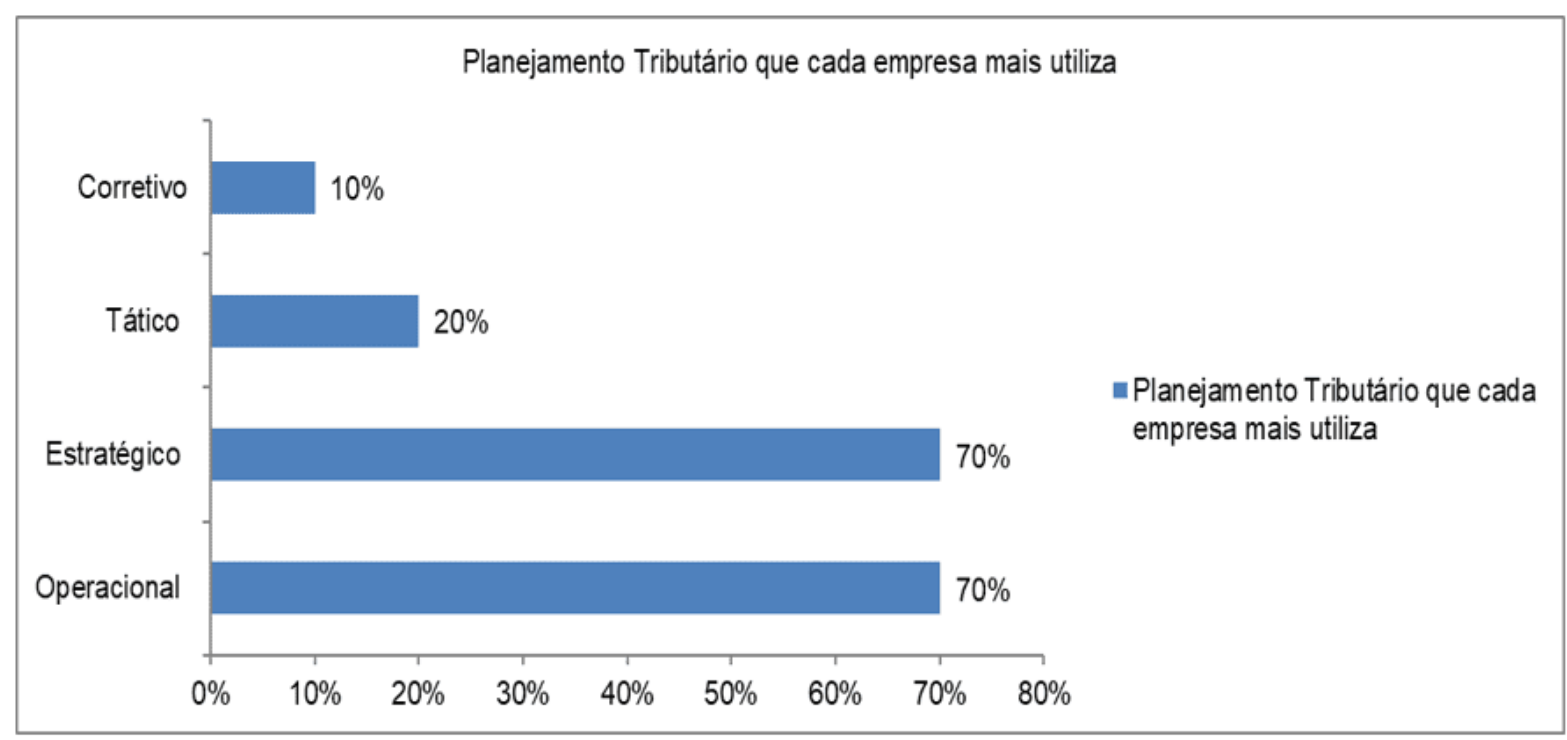

Fonte: Dados da pesquisa 2020.

No gráfico a seguir revela-se que $(90 \%)$ de nossos respondentes afirmaram que desconhecer a existência e o pagamento de forma indevida dos tributos, fator esse que pode vir a prejudicar o crescimento da empresa e somente (10\%) afirmou de forma contrária aos demais. 
Gráfico 8 - Conhecimento dos empresários em relação ao pagamento de tributos

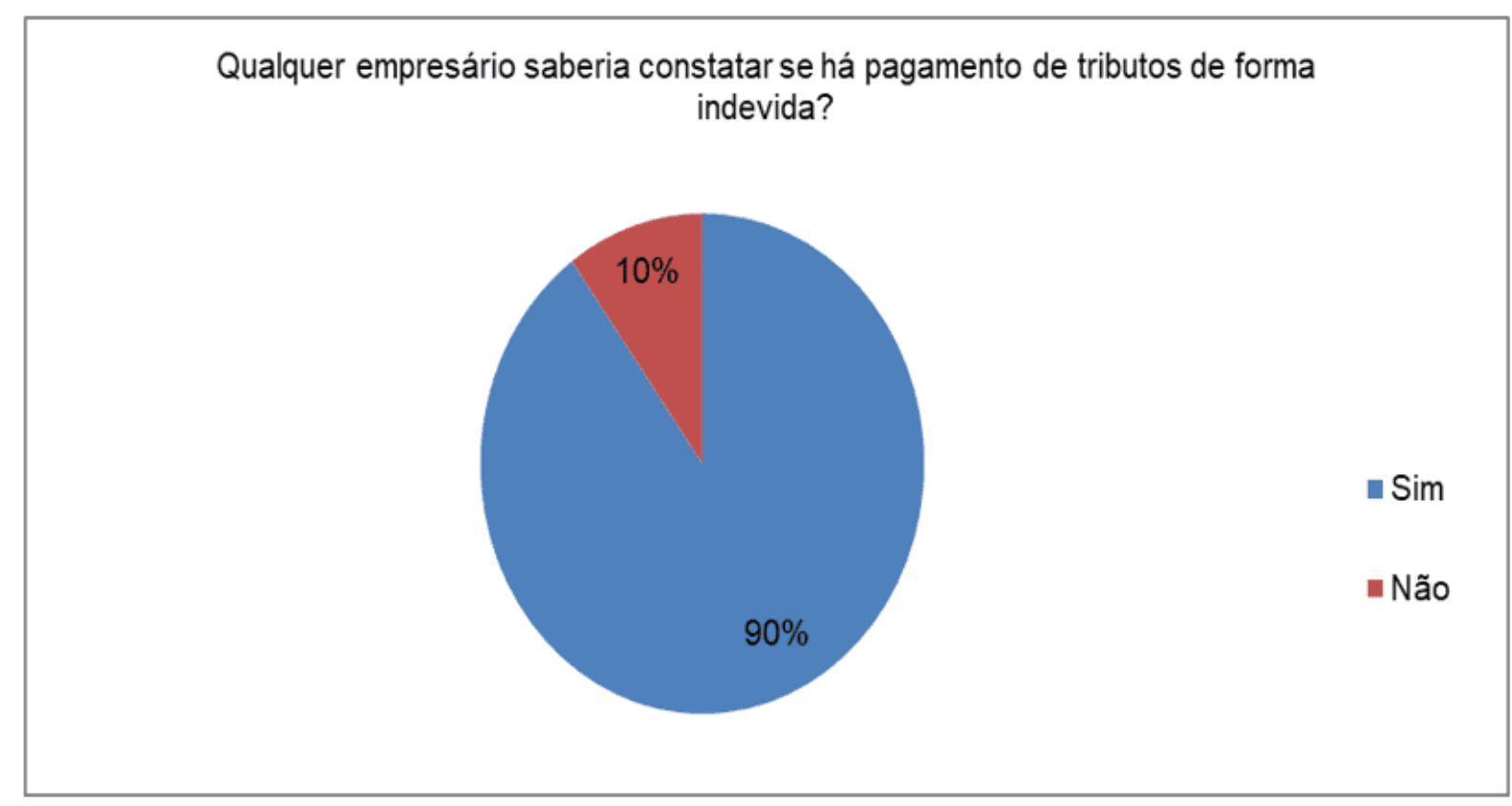

Fonte: Dados da pesquisa 2020.

Quanto ao controle de entradas e saídas das notas fiscais, no gráfico a seguir, mostra que $80 \%$ dos respondentes revelam que faz o controle das notas e $20 \%$ afirmam que não. 
Gráfico 9 - Controle de notas fiscais

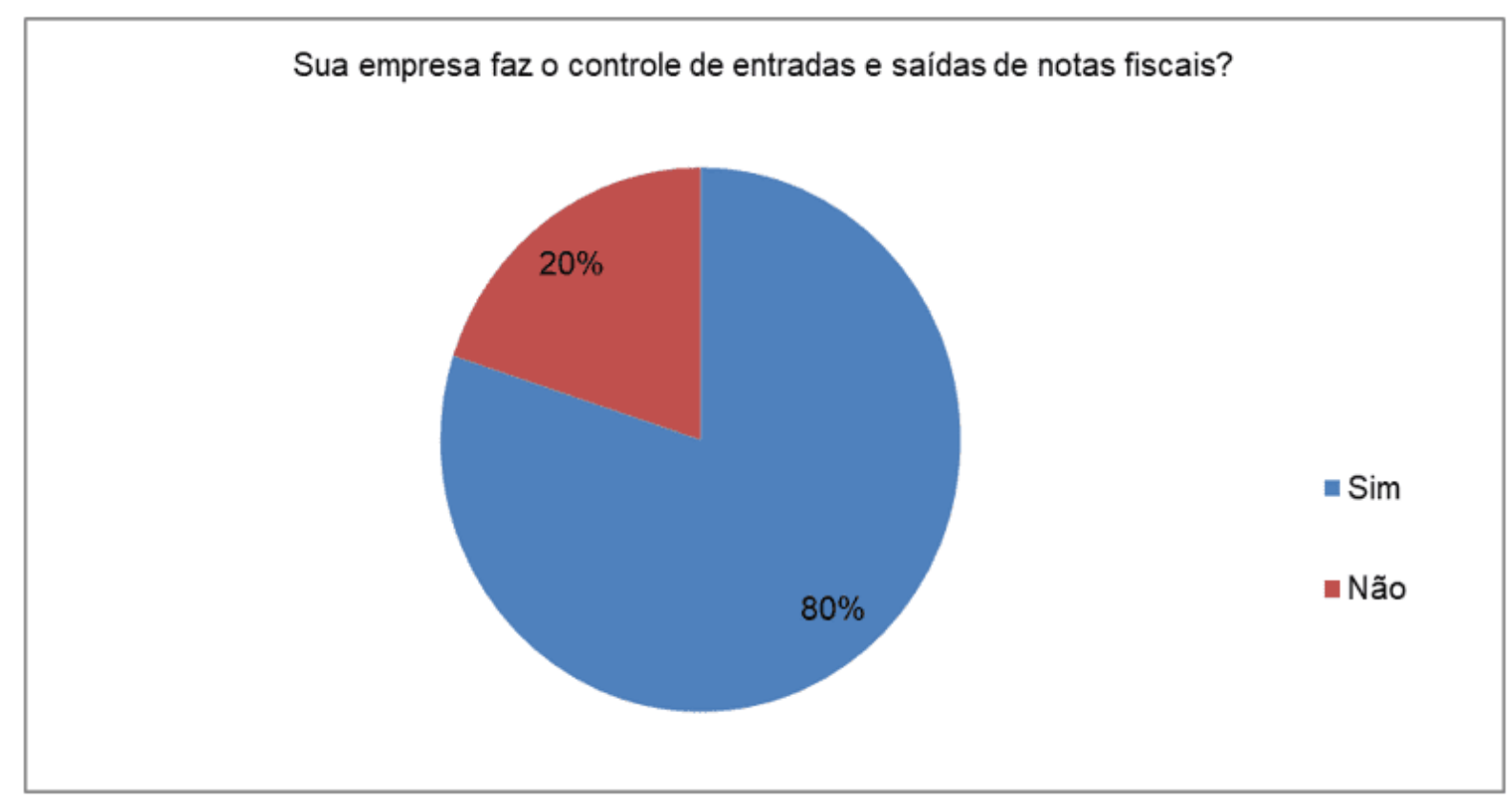

Fonte: Dados da pesquisa 2020.

No gráfico abaixo, os respondentes relatam as dificuldades encontradas durante o período de recuperação tributária. Destacando com o maior percentual $(70 \%)$ a desorganização da documentação e a inconsistência nas informações. Podemos observar que os gráficos 9 e 10 se correlacionando quando há falta de um controle interno nas práticas das empresas gerando dificuldades para se recuperar o crédito. 
Gráfico 10 - Identificação de problemas na recuperação tributária

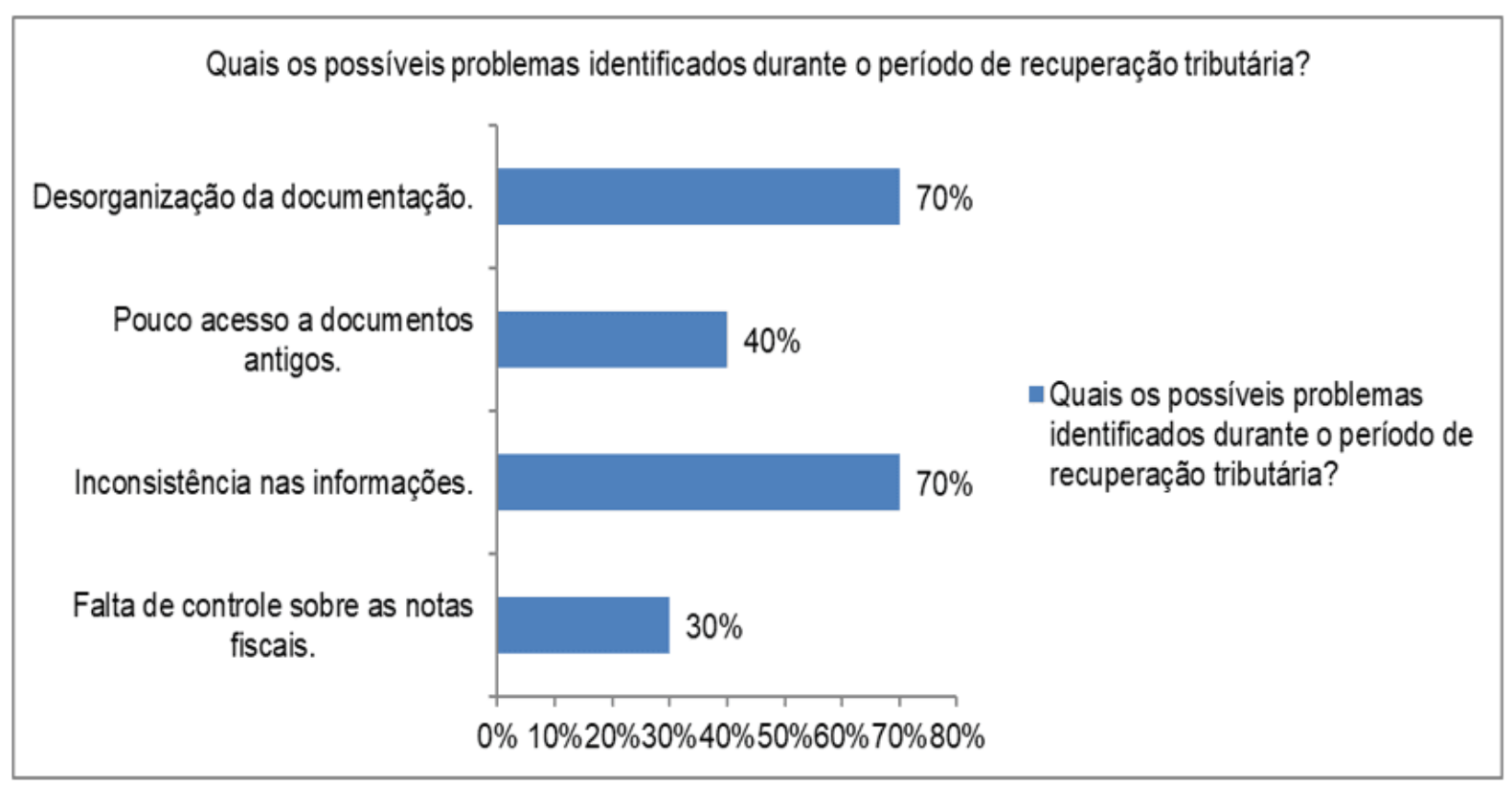

Fonte: Dados da pesquisa 2020.

Os fatores que são determinantes para decidir o melhor regime de tributação para a empresa, considerando as informações dos respondentes conforme o gráfico abaixo, $90 \%$ acham que a verificação das normas legais para o enquadramento nos regimes tributários. Enquanto $60 \%$ acham que a comparação dos sistemas de tributação junto à realização de um estudo sobre o histórico da empresa verificando a ocorrência do fato gerador de tributos. 
Gráfico 11 - Escolha de regime tributário

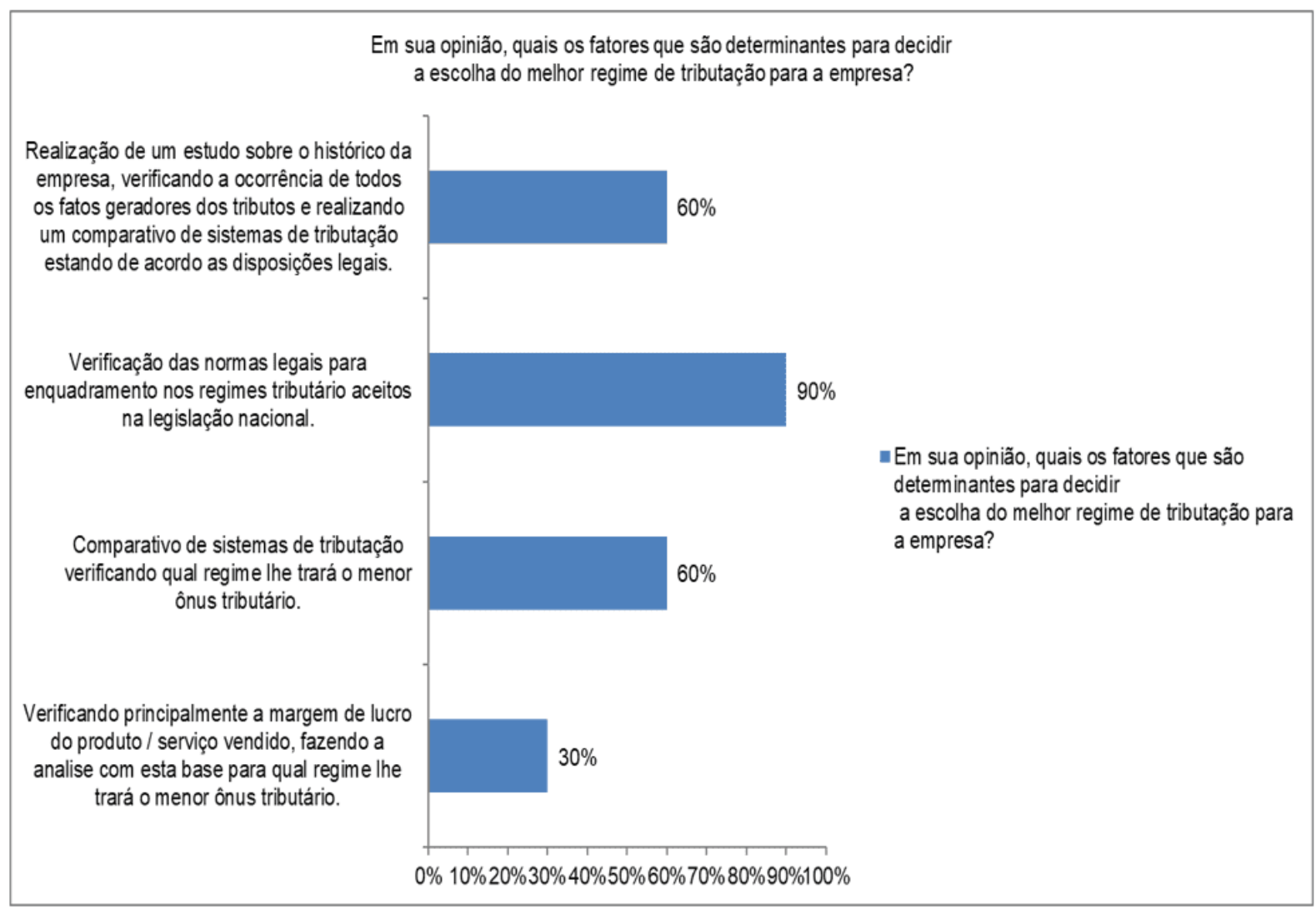

Fonte: Dados da pesquisa 2020.

Ciente da importância da habitualidade do planejamento tributário e que a nossa realidade muda a todo instante por conta de fatores externos e internos, é preciso que as empresas tenham a percepção de manter esse processo atualizado para que se conquistem melhores resultados e segurança operacional. Segundo dados da pesquisa nos revelam que $40 \%$ de nossos respondentes fazem planejamento tributário de forma mensal, $10 \%$ semestral, $10 \%$ anual e 10\% não faz, como nos mostra o gráfico abaixo. 
Gráfico 12 - Periodicidade de execução do planejamento tributário

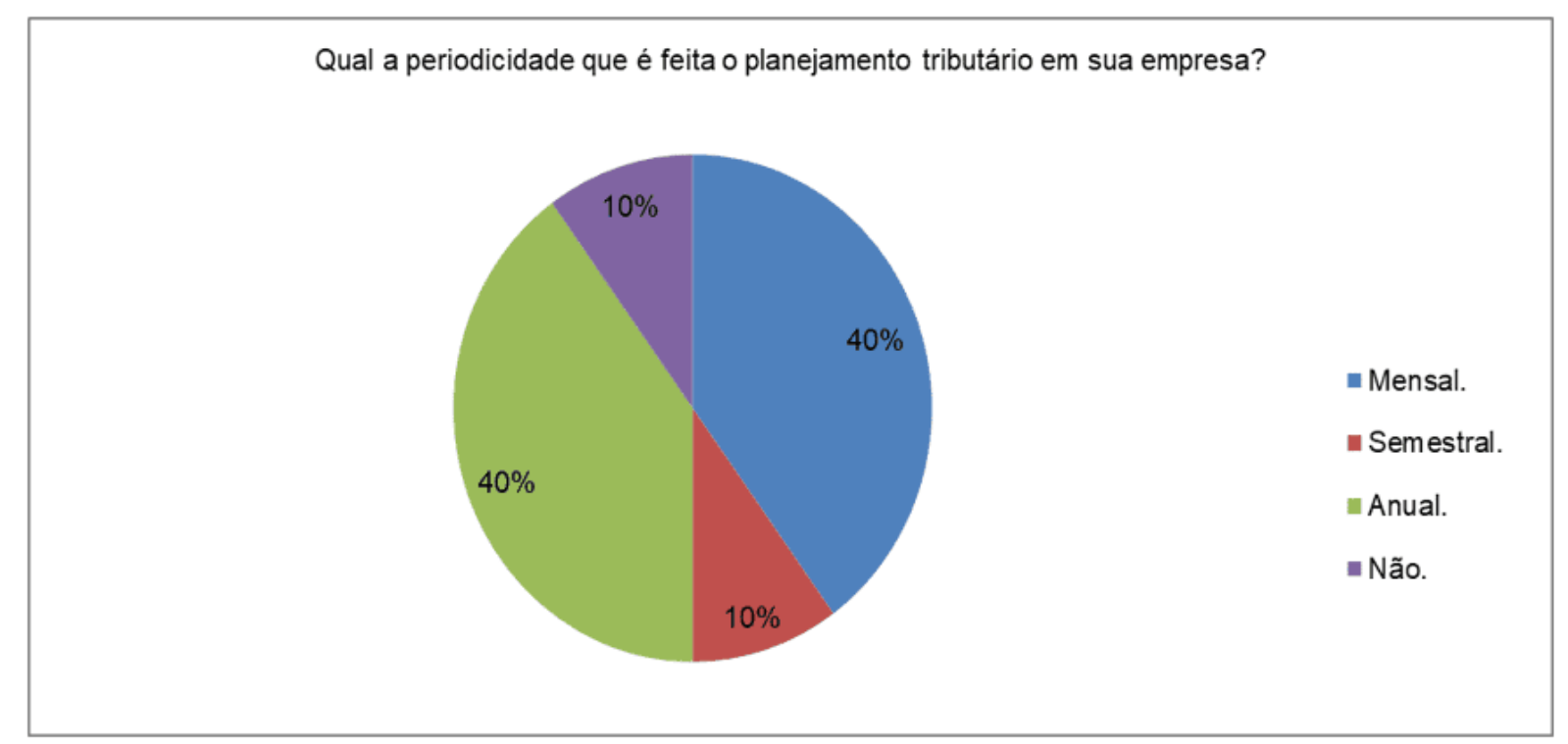

Fonte: Dados da pesquisa 2020.

No gráfico a seguir, os respondentes relataram a importância de se fazer o planejamento tributário. Com maior percentual (90\%), sendo de grande complexidade a alta carga tributária da legislação nacional, como pagamento indevido dos tributos e a competitividade das empresas. 
Gráfico 13 - Importância de se ter um planejamento tributário

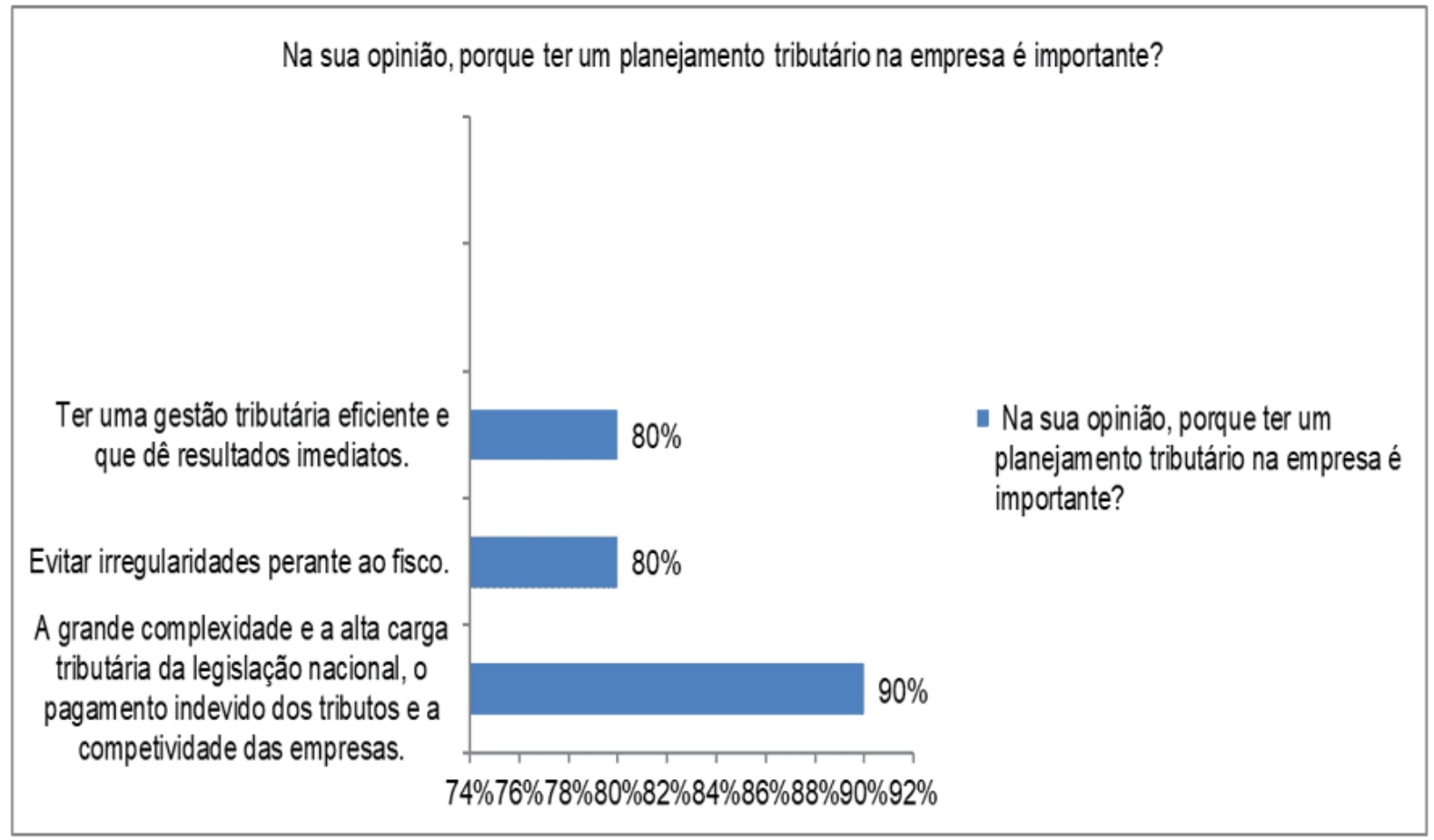

Fonte: Dados da pesquisa 2020.

Questionado sobre as práticas mais importantes em um processo de recuperação de créditos, obtivemos que devido à complexidade e a alta carga tributária existente no Brasil. Segundo o Banco Mundial (2019), "as empresas brasileiras levam em média 2.600 horas por ano para realizar todos os procedimentos necessários para honrar com suas obrigações tributárias, o que representa mais de 10 vezes a média mundial".

Dentre essas preocupações podemos citar a falta de conhecimento as leis tributárias e para isso são necessárias algumas práticas para agilizar e ter êxito no processo, de acordo com nossos respondentes implementar, aprimorar, monitorar, revisar, controlar, organizar processos digitais, montar de um plano tributário para um melhor enquadramento tributário para a empresa são primordiais. 
Como mostra no gráfico a seguir, com o maior percentual $100 \%$ fala que as dificuldades encontradas pela empresa para implantação do planejamento tributário está na complicada legislação tributária, fato este que mais contribui para o aumento dos custos, restrições de acesso e falta de comunicação entre os órgãos públicos e as empresas, dificuldade de estruturação na área fiscal da empresa e falta de conhecimento, tornando a manutenção da mesma complexa, onerosa e que pode vir a causar dúvidas na cabeça de todo empreendedor, podendo levar a erros na hora de recolher os seus impostos.

Gráfico 14 - Dificuldades na implantação do planejamento tributário

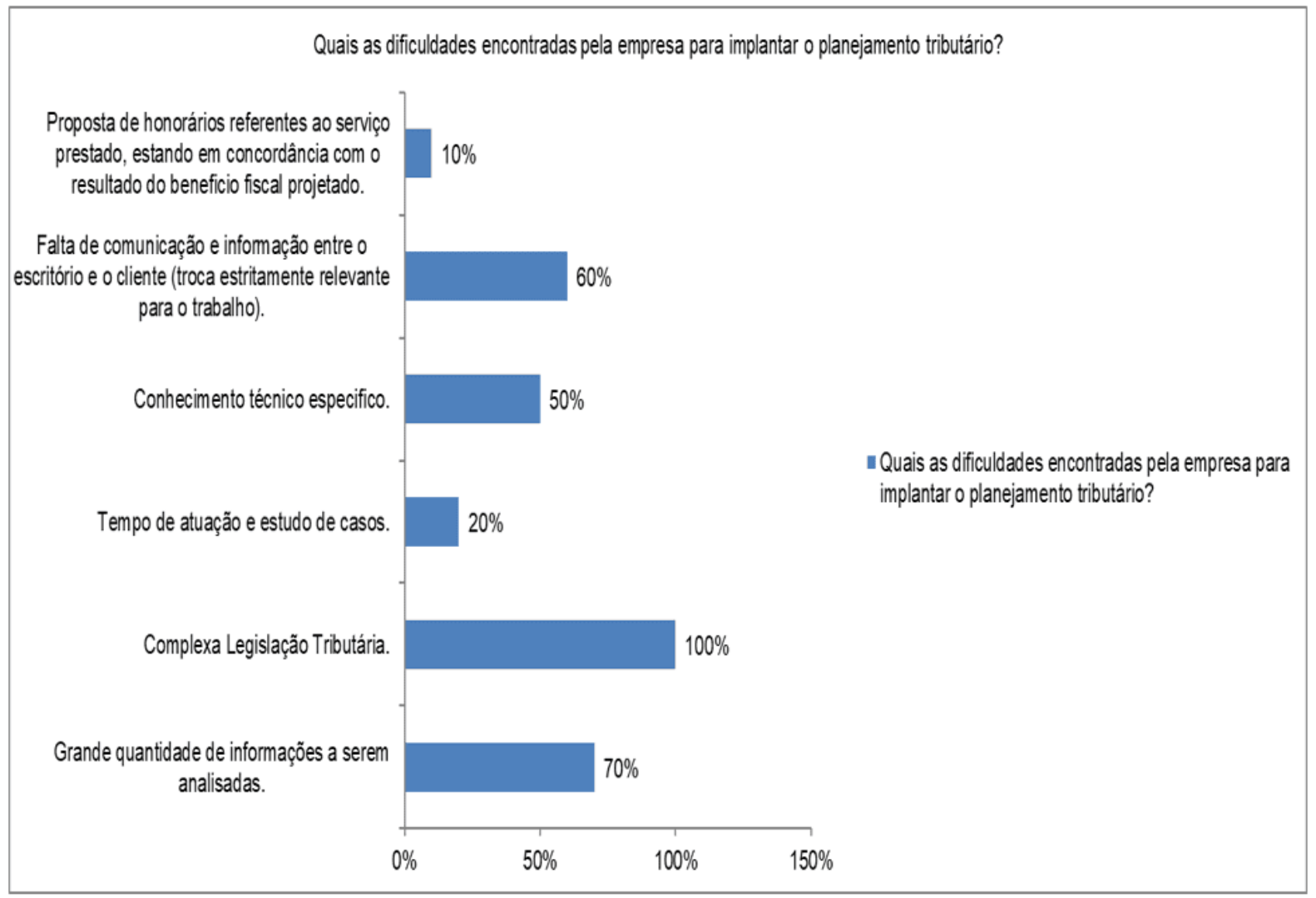

Fonte: Dados da pesquisa 2020.

Ao perguntar sobre os benefícios que o compliance já trouxe para as empresas, $80 \%$ falam que um dos benefícios foi o fim de gastos extras com tributos como mostra no gráfico a frente. Conhecer o seu negócio, entender quais são as regras 
que devem ser seguidas para garantir a segurança jurídica e aplicá-las na sua rotina, são excelentes maneiras de contribuir para o desenvolvimento saudável e o crescimento sustentável. Desta forma, investir em compliance e garantir uma assessoria de qualidade são diferenciais que contribuirão para uma gestão de custos mais efetiva.

Gráfico 15 - Benefícios do compliance

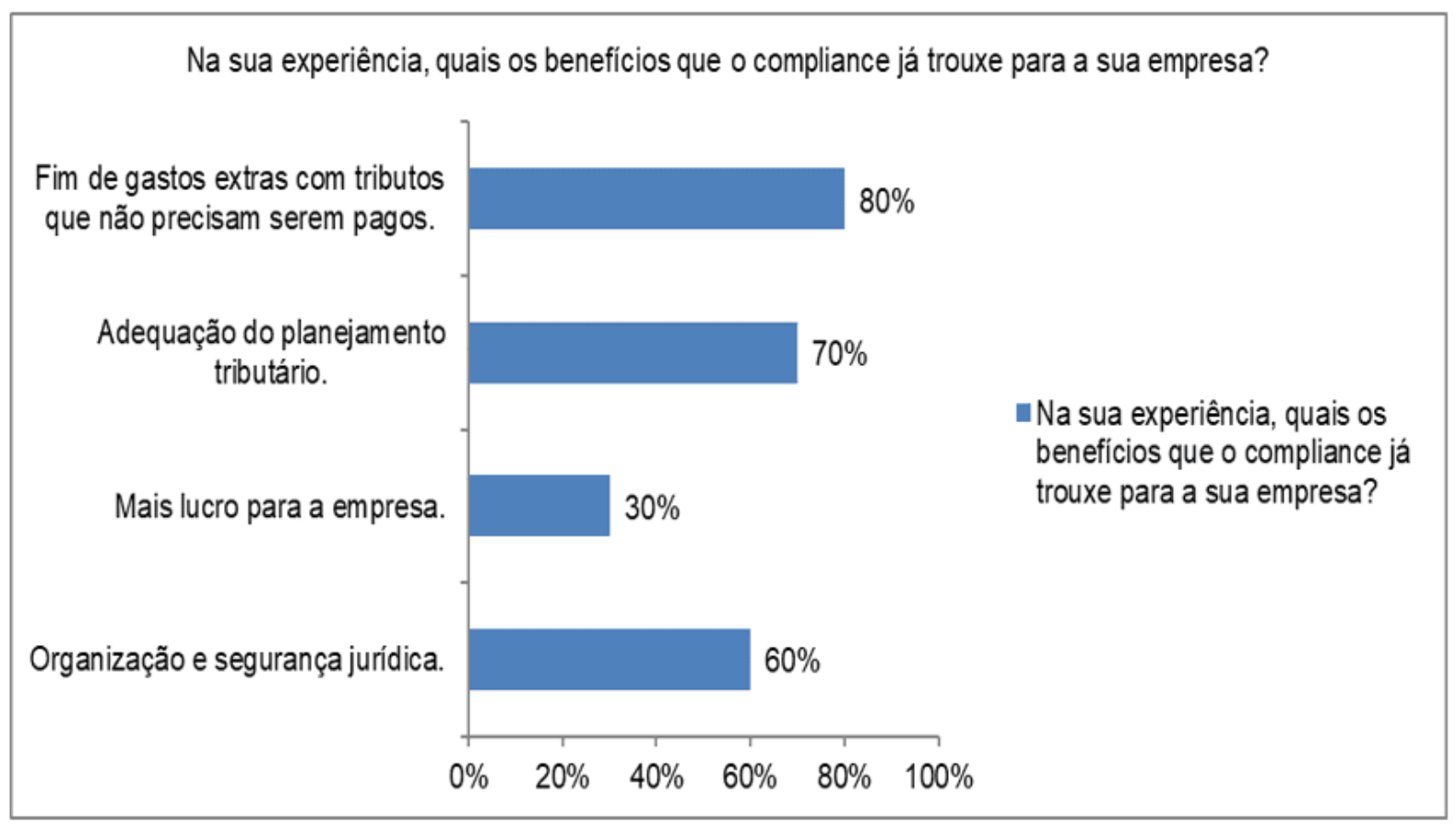

Fonte: Dados da pesquisa 2020.

No gráfico apresentado a seguir, destaca-se que 100\% dos respondentes relataram que o monitoramento e medição é a estrutura mais adequada para que o objetivo do compliance seja alcançado.

As práticas de compliance estão baseadas em pessoas e processos operacionais e tecnológicos. Até a rotatividade das pessoas nas organizações pode comprometer a qualidade das apurações. Os processos carecem de uma estrutura básica mínima de tecnologia que permita verificar e garantir que a execução siga os planos existe o risco de que o planejamento tributário se torne insuficiente. A falha vai acontecer não 
devido ao planejamento em si, e sim pela falta de métodos e rotinas que deveriam ser mantidos ao longo dos anos e se perderam.

Baseado nos procedimentos fica bastante difícil que as rotinas apesar de serem essenciais sejam mantidas no decorrer dos anos, por isso temos visto com frequência as organizações usarem tecnologias que ajudam as pessoas a manterem os processos ativos, a fim de manter em compliance as empresas estabelecendo o início do que foi planejado.

Gráfico 16 - Estrutura adequada para o alcance do compliance

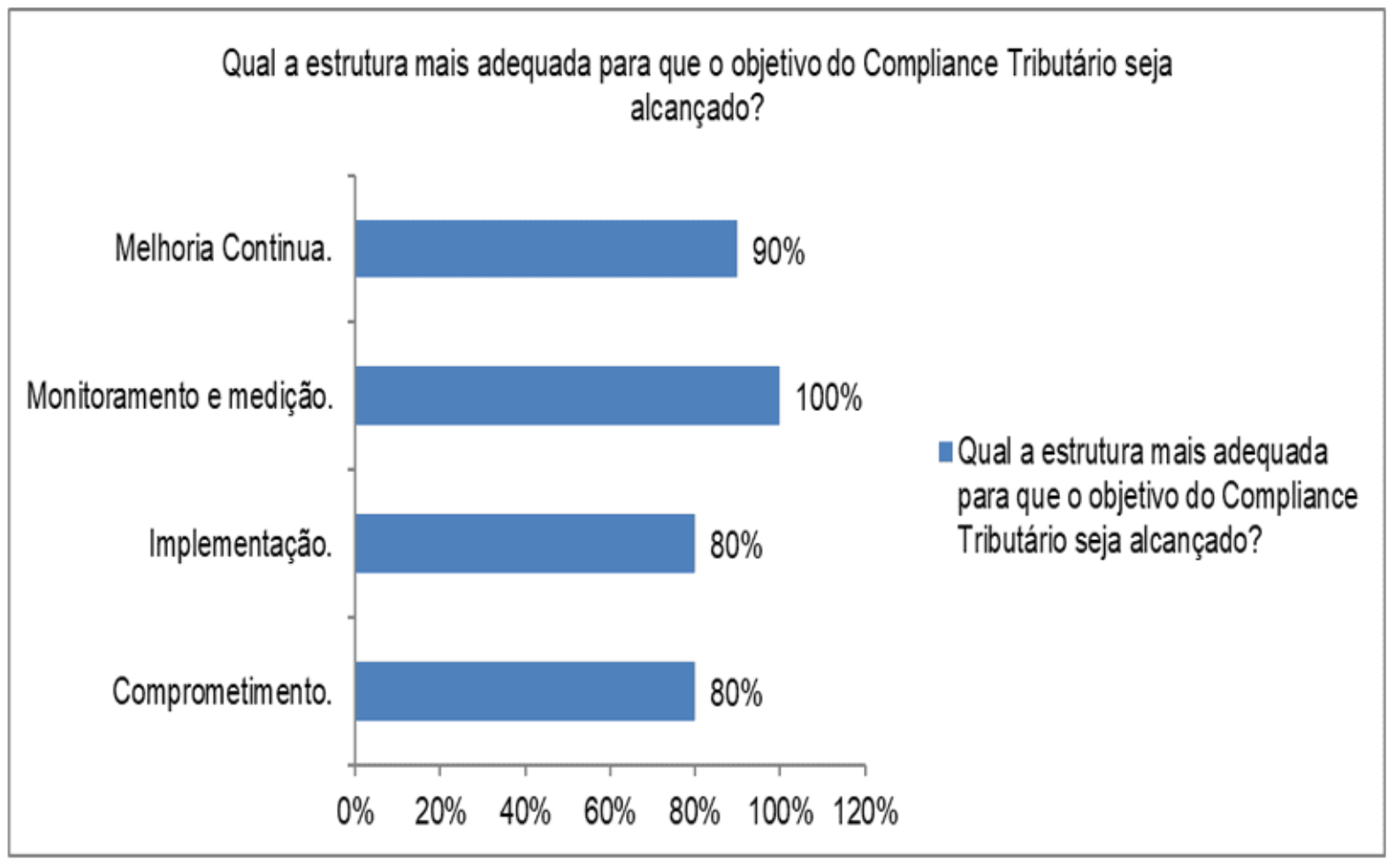

Fonte: Dados da pesquisa 2020.

O próximo gráfico, mostra que com $90 \%$ a geração de custos é identificada como um dos maiores problemas que a empresa já enfrentou por falta de compliance / planejamento tributário para recuperar tributos. Cabe aos empresários e empreendedores buscarem profissionais habilitados na área para realizar um efetivo 
planejamento tributário, minimizando os riscos econômicos e jurídicos de tal operação.

Gráfico 17 - Problemas enfrentados na recuperação de créditos

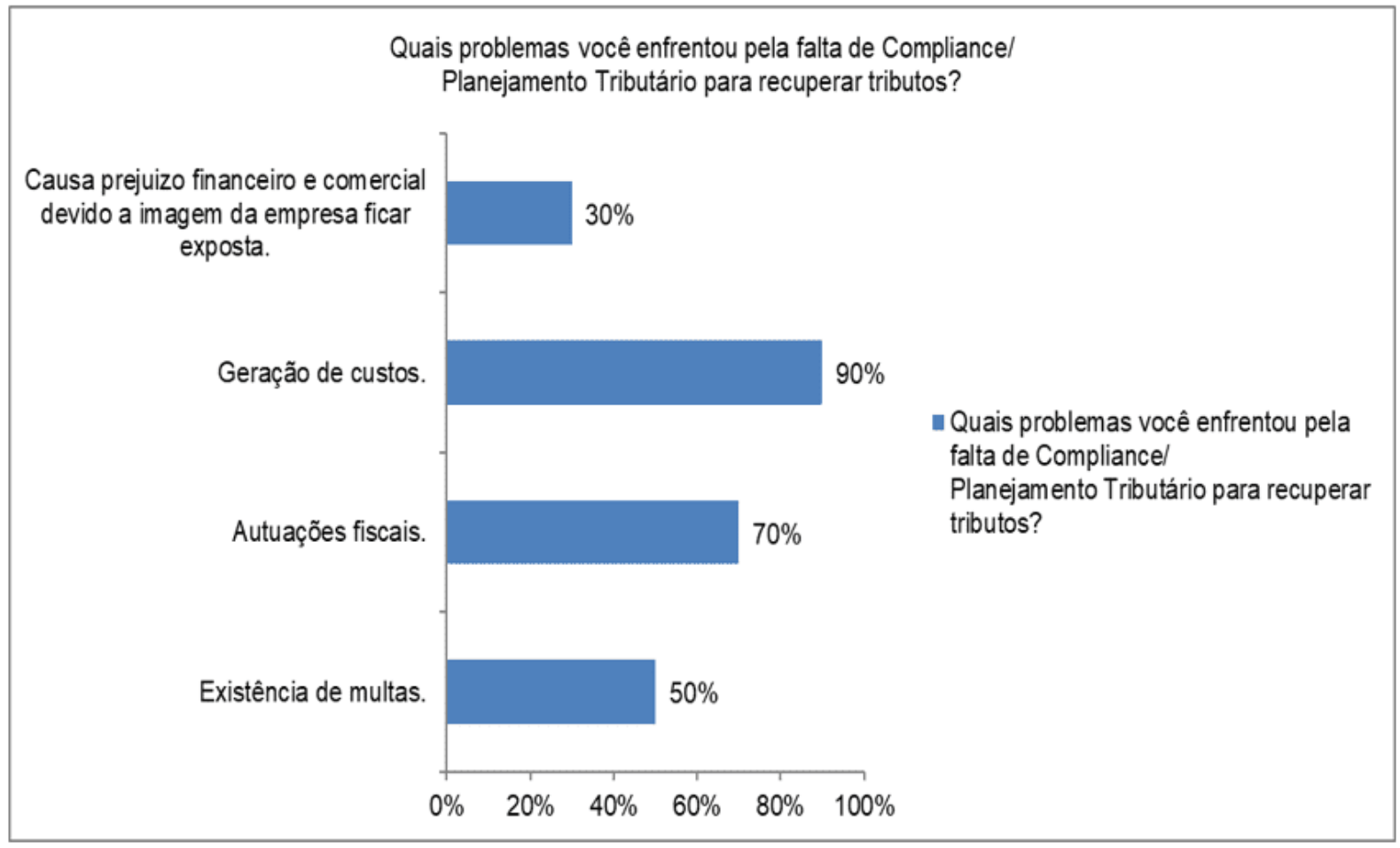

Fonte: Dados da pesquisa 2020.

Quando questionamos quais práticas de compliance / planejamento tributário teria ajudado caso tivessem sido utilizadas antes do processo de recuperação de tributos. Obtivemos respostas de forma personalizada, sobre os controles internos que deveriam ser utilizado nas práticas da empresa, tais como, visão empresarial ampla com maior de comprometimento por parte dos gestores, conhecimento técnico, organização interna facilitando o acesso das informações necessárias para o processo de recuperação, análises documentais constantes e auditorias internas para garantir a autonomia e ser imparcial nas ações, tais práticas têm como pressuposto serem íntegras, eficientes e independentes, para que não se apenas mais um procedimento burocrático. 
Com o gráfico à frente, mostra a necessidade de se fazer uma revisão fiscal. Sendo que, $50 \%$ fazem a revisão mensal, outros $20 \%$ semestral e anual, enquanto $10 \%$ não faz. E para isso, o ideal é que se faça uma revisão tributária a cada 6 meses, ou pelo menos anualmente. Já para as empresas que nunca revisaram seus impostos, que faça o quanto antes, pois a prescrição dos créditos tributários acontece ao final do quinto ano, ocasionando a perda do direito de recuperação dos tributos.

Gráfico 18 - Necessidade de revisão fiscal

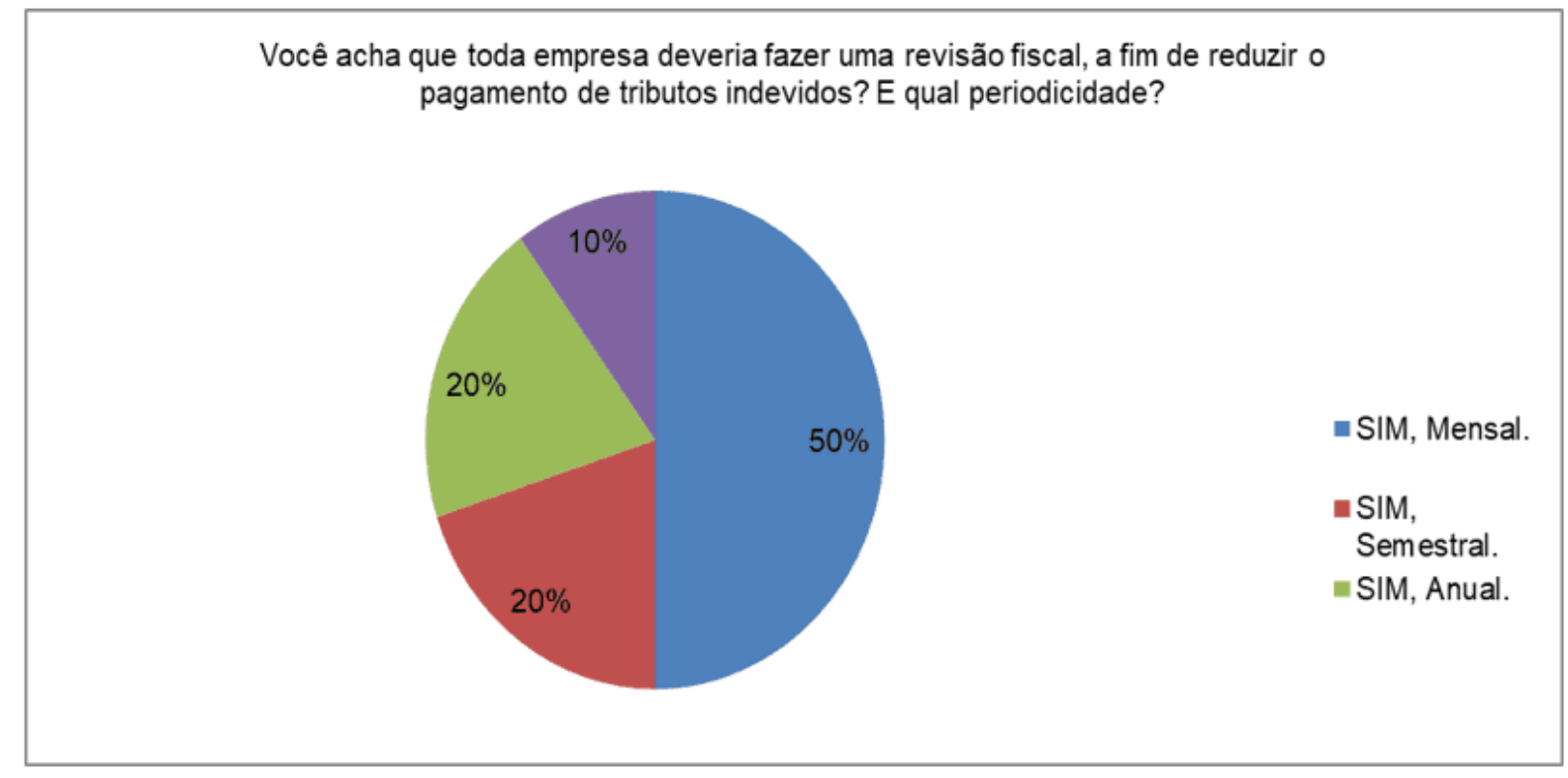

Fonte: Dados da pesquisa 2020.

No gráfico a seguir, a enquete ficou dividida, sendo 50\% afirmado que sim, isso trará fiscalização outros $50 \%$ disseram que não. Apurar o histórico contábil de uma empresa pode ser um tanto quanto desafiador em certas situações a verdade é que, sem a percepção as empresas já sofrem constantes fiscalizações do governo e as empresas acabam sendo sempre penalizadas. Por não agir, montantes em tributos recolhidos indevidamente e que poderiam ter sido restituídos, tanto quanto para o pagamento de débitos de impostos em atraso quanto para uso do valor no reabastecimento do seu fluxo de caixa. 
Gráfico 19 - Fiscalização na recuperação de crédito

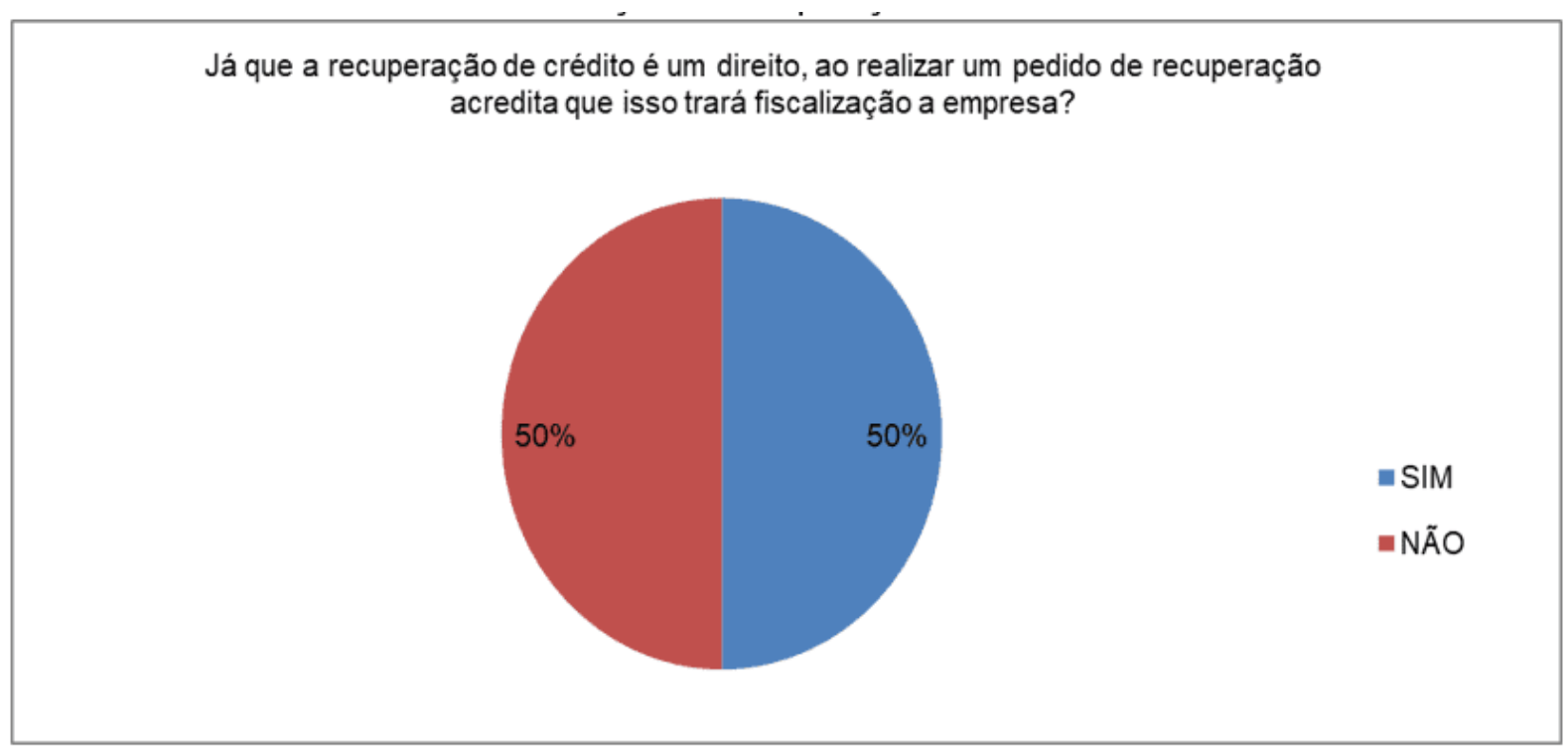

Fonte: Dados da pesquisa 2020.

Tivemos opiniões variadas, quando abordado sobre se as práticas de compliance e planejamento tributário existente na empresa contribuíram para o êxito do processo de recuperação, mas que no contexto geral nos resulta em uma análise bem enxuta e concreta de fácil definição, pois a recuperação existe a partir do momento em que não agimos de acordo a com legislação.

Como mostra no próximo gráfico $40 \%$ consideraram a recuperação de crédito como uma opção de aumento de receita em momentos de pandemia, optando por restituir o crédito recuperado. $30 \%$ consideraram também como aumento de receita sendo utilizado como compensação do crédito e os outros $30 \%$ não considera uma opção de aumento de receita. 
Gráfico 20 - Recuperação de crédito como opção de receita

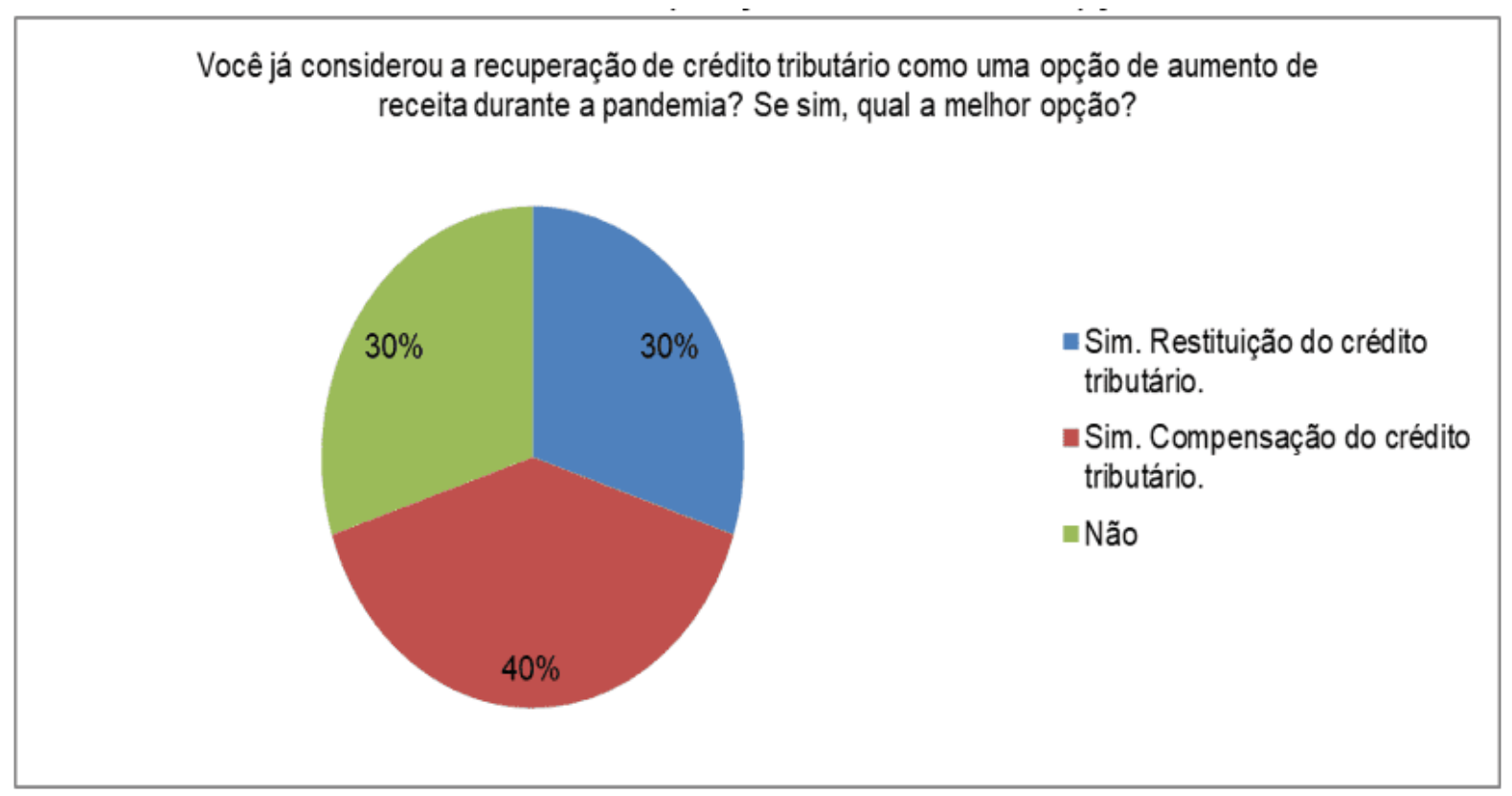

Fonte: Dados da pesquisa 2020.

Em tempos de crise, a recuperação de crédito pode significar um aliado para as empresas se manterem no mercado. Aquele crédito que se tem para receber pode ajudar as empresas a enfrentarem momentos difíceis como este que estamos vivendo. Muitos empresários desconhecem como se deve proceder a recuperação de créditos e as ferramentas como o compliance / planejamento tributário que tem intuito de reduzir os custos e aumentar o caixa da empresa.

\section{CONSIDERAÇÕES FINAIS}

A presente pesquisa teve como objetivo analisar a influência do compliance / do planejamento tributário na recuperação de créditos. Ao decorrer da pesquisa e com a análise do questionário, observamos que os fatores prejudiciais nas empresas são a alta carga tributária e o desconhecimento por parte dos dirigentes frente à legislação, pois não utilizam de forma adequada as estratégias tributárias, deixando de se beneficiar das vantagens que pode obter com o compliance / planejamento tributário, que além de ser uma alternativa para a redução de custos é visto também 
como oportunidade competitiva de mercado. O planejamento tributário deve sempre observar conscientemente a legislação com a finalidade de mostrar ao contribuinte a carga tributária mais vantajosa. E não deve ser confundido com a Evasão Fiscal (sonegação), por se tratar de uma atuação lícita.

Sabemos que hoje existe o discernimento de que as empresas enfrentam o impacto financeiro da tributação, além dos investimentos despendidos na estruturação de uma equipe preparada e a tecnologia necessária para a apuração dos tributos. Durante a pesquisa percebemos que o planejamento tributário quando alinhado ao compliance, potencializa a capacidade empreendedora com a possibilidade de aumento de suas receitas e reservas de caixa, onde pode ser destinada a realização de novos investimentos que consequentemente crescimento e aprimoramento das atividades desenvolvidas nesse período pandêmico.

A boa gestão de uma empresa depende de vários fatores e um dos mais importantes destes é o planejamento tributário, segundo 90\% dos respondentes. Entretanto, esbarram nas dificuldades para realizá-los, sendo o mais agravante para os respondentes a geração de custos, mas com uma revisão fiscal minucioso mensal segundo $50 \%$ dos respondentes ajudaria na redução dos pagamentos de impostos e até uma geração de receitas através da recuperação de créditos, com práticas simples e eficientes de compliance e planejamento tributário.

À face do exposto, certificamos que a recuperação tributária está disponível para empresas dos três regimes tributários existentes no Brasil. Recomenda-se que as empresas coloquem a recuperação de crédito tributário no radar, uma vez que pode representar uma excelente opção para a geração de caixa, principalmente agora de crise econômica e sanitária que o Brasil e o mundo vivenciam, diante da pandemia do Covid-19. 


\section{REFERÊNCIAS}

ABBI - Associação Brasileira de Bancos Internacionais e FEBRABAN - Federação Brasileira de Bancos. Função de compliance. 07/2003. Disponível em: http://www.abbi.com.br/download/funcaodecompliance09.pdf. Acesso em: 20/04/2020.

BESSA, T. A relevância da adoção do compliance tributário pelas empresas. 15/04/2019. Disponível em: https://www.compliancepme.com.br/artigos/compliancetributario-importancia-e-riscos-20190415. Acesso em: 15/06/2020.

CASTRO, Vanessa Gomes de. A importância do compliance e o planejamento tributário para as empresas perante as normas e regras de tributação do Brasil. 10/2019. Disponível em: https://jus.com.br/artigos/77239/a-importancia-docompliance-e-o-planejamento-tributario-para-as-empresas-perante-as-normas-eregras-de-tributacao-do-brasil. Acesso em: 25/11/2020.

COIMBRA, Marcelo de Aguiar; MANZI, Vanessa Alessi. Manual de compliance. São Paulo: Editora Atlas, 2010.

COSTA, Maria das Dores Araújo Evaristo. A percepção do contador em relação ao compliance tributário. 07/2019. Disponível em: https://assets.ipog.edu.br/wpcontent/uploads/2019/12/07015621/maria-das-dores-araujo-evaristo-costa17181357.pdf. Acesso em: 10/11/2020.

CREPALDI, Silvio. Planejamento tributário: teoria e prática. 4. ed. São Paulo: Saraiva Educação, 2021.

DOME EXPERTISE TRIBUTÁRIA. O que é o processo administrativo de recuperação tributária no âmbito federal. 23/09/2019. Disponível em: https://vempradome.com.br/blog/o-que-e-o-processo-administrativo-de-recuperacaotributaria-no-ambito-federal/. Acesso em: 25/11/2020. 
FEITOSA, Anderson. Quais são os tipos de planejamento tributário e como colocar em prática. 02/09/2020. Disponível em: https://conube.com.br/blog/tiposde-planejamento-tributario/. Acesso em: 31/10/2020.

GIOVANINI, Wagner. Compliance: a excelência na prática. 1aㅡ Ed. São Paulo. 2014.

IBPT - Instituto Brasileiro de Planejamento Tributário, você sabe como se deu a origem da tributação no Brasil? Disponível em: https://educacao.ibpt.com.br/blog/origem-da-tributacao-no-brasil/. Acesso em: 10/11/2020.

LIMA, Diran Aquino de. Recuperação de crédito tributário no Simples Nacional. 26/11/2019. Disponível

em: https://www.direitonet.com.br/artigos/exibir/11410/Recuperacao-de-credito-tributarionoSimplesNacional\#: :text=Ap\%C3\%B3s\%20a\%20apura\%C3\%A7\%C3\%A30\%20d os\%20valores,no\%20portal\%20do\%20Simples\%20Nacional. Acesso em: 28/10/2020.

LIMA, Emanoel Marcos; REZENDE, Amaury José. Um estudo sobre a evolução da carga tributária no Brasil: uma análise a partir da Curva de Laffer. Disponível em: https://www.scielo.br/pdf/inter/v20n1/1518-7012-inter-20-01-0239.pdf._Acesso em: 10/11/2020.

LUKIC, Melina Rocha. Planejamento tributário. Disponível em: https://direitorio.fgv.br/sites/direitorio.fgv.br/files/u1882/planejamento tributario 2017 -1.pdf. Acesso em: 15/05/2020.

MENDES, Cristiane Soares. Entenda como funciona o processo de recuperação de crédito tributário. Disponível em: https://cristianesoaresmendes.jusbrasil.com.br/artigos/520057450/entenda-comofunciona-o-processo-de-recuperacao-de-credito-tributario. Acesso em: 31/10/2020. 
MINISTÉRIO PUBLICO FEDERAL, Caso lava jato. Disponível em: http://www.mpf.mp.br/grandes-casos/lava-jato/entenda-o-caso.

MOREIRA, Eliane de Oliveira. Compliance no Brasil: aspectos da responsabilidade fiscal das empresas no combate à corrupção. Disponível em: http://revistajuridica.esa.oabpr.org.br/wpcontent/uploads/2018/09/revista_esa_7_14.p df. Acesso em: 31/10/2020.

OLIVEIRA, Gustavo Pedro de. Contabilidade tributária. 3. ed. São Paulo: Saraiva, 2013.

OLIVEIRA, Luis Martins de. et al. Manual da contabilidade tributária: textos e teses com respostas, 13 ed, São Paulo: Atlas, 2014.

REAL MARKETING. Recuperação de crédito tributário: entenda o processo. 23/10/2019. Disponível em: https://contreal.com.br/recuperacao-de-credito-tributarioqual-o-processo/. Acesso em: 23/10/2020.

REDAÇÃO GRUPO STUDIO, Como funciona a revisão tributária para empresas do Simples Nacional, 27/03/2019, Disponível em https://blog.grupostudio.com.br/efiscal/como-funciona-a-revisao-tributaria-para-empresas-do-simples-nacional/. Acesso em: 10/11/2020.

REDE JORNAL CONTABIL. Recuperação de crédito tributário: Saiba o que é e como isso pode ajudar o seu negócio. 23/05/2020. Disponível em: https://www.jornalcontabil.com.br/recuperacao-de-credito-tributario-saiba-o-que-e-ecomo-isso-pode-ajudar-o-seu-negocio/. Acesso em: 03/05/2020.

REVISTA AMBITO JURIDICO. A relevância da adoção do compliance tributário pelas empresas. 01/05/2018. Disponível em: https://ambitojuridico.com.br/edicoes/revista-172/a-relevancia-da-adocao-docompliance-tributario-pelas-empresas/.. Acesso em: 20/06/2020. 
RIZZARDO, Arnaldo. Parte geral do código civil. Rio de Janeiro: Forense, pág. 16, 2003.

SANTOS, Nashila. Recuperação de crédito tributário - Tudo o que você precisa saber para oferecer uma consultoria completa. Disponível em: https://www.gestta.com.br/recuperacao-de-credito-tributario-tudo-o-que-voceprecisasaber/\#. Acesso em: 22/10/2020.

SANTOS, Erica Lucia dos; BRITO, Leandro Carvalho de. Planejamento tributário como ferramenta na tomada de decisão. 2016, Disponível em: https://semanaacademica.org.br/system/files/artigos/artigo_planejamento_tributario.p df. Acesso em: 12/07/2021.

SIQUEIRA, Eurípedes Bastos; CURY, Locordaire Kemel Pimenta; GOMES, Thiago Simões. Planejamento tributário. Revista CEPPG - CESUC, n. 25, v.2, p.184-196, 2011.

SOARES, Marcela. Planejamento tributário e compliance. Disponível em: https://ieadireito.jusbrasil.com.br/artigos/652247090/planejamento-tributario-ecompliance. Acesso em: 31/10/2020.

SOUZA, Luciane Regina Braçaroto de; PAVÃO, Ana Celi. A necessidade do planejamento tributário visando a redução dos custos nas organizações. 09/2012, Disponível em: https://www.inesul.edu.br/revista/arquivos/ arq-idvol 19_1346771456. pdf. Acesso em: 15/06/2020.

VIEGAS, Amaranto Crepaldi. Compliance e recuperação tributária- 0 impacto no fluxo de caixa nas empresas. 23/02/2018. Disponível em: http://acv.adv.br/compliance-e-recuperacao-tributaria-o-impacto-no-fluxo-de-caixadas-empresas/.. Acesso em: 24/10/2020. 
ZANLUCA, Julio Cézar. Planejamento tributário. Disponível em: http://www.portaltributario.com.br/planejamento.htm\#: :text=0\%20planejamento\%20 tribut\%C3\%A1rio\%20\%C3\%A9\%20um,seu\%20empreendimento\%2C\%20inclusive\% 20dos\%20impostos. Acesso em: 14/06/2020.

\section{ANEXO A}

Questionário sobre a influência do compliance tributário e planejamento tributário na recuperação de tributos ${ }^{[4]}$

1 - Qual é o seu cargo na empresa?

2 - Em qual município está localizado a empresa?

3 - Há quanto tempo a empresa existe?

4 - Tipo de Empresa?

5 - Qual o segmento da Empresa?

6 - Diante do conceito acima citado, quais práticas de Planejamento Tributário sua empresa utiliza?

7 - Diante do conceito acima, quais práticas de compliance tributário sua empresa utiliza?

8 - Qual o tipo de Planejamento Tributário que a sua empresa mais utiliza?

9 - A recuperação de crédito é importante para as empresas?

10 - Qualquer empresário saberia constatar se há pagamento de tributos de forma indevida? 
11 - Seguindo o conceito de compliance, sua empresa faz o controle de entradas e saídas de notas fiscais?

12 - De acordo com sua resposta acima, quais os possíveis problemas identificados durante o período de recuperação tributária?

13 - A escolha de um regime de tributação eficaz faz a diferença na empresa?

14 - Em sua opinião, quais os fatores que são determinantes para decidir a escolha do melhor regime de tributação para a empresa?

15 - Qual a periodicidade que é feita o planejamento tributário em sua empresa?

16 - Na sua opinião, por que ter um planejamento tributário na empresa é importante?

17 - Quais práticas de compliance / Planejamento Tributário são importantes para um processo de recuperação tributária?

18 - Quais as dificuldades encontradas pela empresa para implantar o planejamento tributário?

19- Na sua experiência, quais os benefícios que o compliance já trouxe para a sua empresa?

20 - Qual a estrutura mais adequada para que o objetivo do compliance tributário seja alcançado?

21 - Quais problemas você enfrentou pela falta de compliance / planejamento tributário para recuperar tributos?

22 - Quais práticas de compliance / planejamento tributário teria ajudado, caso tivessem sido utilizadas antes do processo de recuperação de tributos? 
23 - Você acha que toda empresa deveria fazer uma revisão fiscal, a fim de reduzir o pagamento de tributos indevidos? E qual periodicidade?

24 - Já que a recuperação de crédito é um direito, ao realizar um pedido de recuperação acredita que isso trará fiscalização a empresa?

25 - Como você acredita que as práticas de compliance e planejamento tributário utilizados na sua empresa, contribuíram para o sucesso de recuperação tributária?

26 - Você já considerou a recuperação de crédito tributário como uma opção de aumento de receita durante a pandemia? Se sim, qual a melhor opção?

\section{APÉNDICE - REFERÊNCIA DE NOTA DE RODAPÉ DO ANEXO A}

4.https://docs.google.com/forms/d/e/1FAlpQLScJEW0AehL4BCW41qAIT8Ex6827yW cDBH75a6O3P0ZVMUFp4A/viewform?usp=sf_link

Enviado: Março, 2021.

Aprovado: Agosto, 2021. 